\title{
Monitoring of the toxic dinoflagellate Alexandrium catenella in Osaka Bay, Japan using a massively parallel sequencing (MPS)-based technique
}

\author{
Satoshi Nagai ${ }^{\mathrm{a}, *}$, Hungyen Chen ${ }^{\mathrm{b}}$, Yoko Kawakami ${ }^{\mathrm{c}}$, Keigo Yamamoto ${ }^{\mathrm{d}}$, Sirje Sildever ${ }^{\mathrm{a}}$, \\ Nanako Kanno $^{a}$, Hiroshi Oikawa ${ }^{a}$, Motoshige Yasuike ${ }^{a}$, Yoji Nakamura ${ }^{a}$, Yuki Hongo ${ }^{a}$, \\ Atushi Fujiwara ${ }^{a}$, Takanori Kobayashi ${ }^{a}$, Takashi Gojobori ${ }^{\mathrm{e}}$ \\ ${ }^{a}$ National Research Institute of Fisheries Science, 2-12-4 Fukuura, Kanazawa-ku, Yokohama, Kanagawa, 236-8648, Japan \\ b Department of Agronomy, National Taiwan University, No. 1, Sec. 4, Roosevelt Rd., Taipei, 10617, Taiwan \\ ${ }^{c}$ AXIOHELIX Co. Ltd, -12-17 Kandaizumicho, Chiyoda-ku, Tokyo, 101-0024, Japan \\ ${ }^{\mathrm{d}}$ Research Institute of Environment, Agriculture and Fisheries, Osaka Prefecture, 2926-1 Tanigawa, Misaki, Sen-Nan, Osaka, 599-0311, Japan \\ ${ }^{\mathrm{e} C o m p u t a t i o n a l ~ B i o s c i e n c e ~ R e s e a r c h ~ C e n t e r, ~ K i n g ~ A b d u l l a h ~ U n i v e r s i t y ~ o f ~ S c i e n c e ~ a n d ~ T e c h n o l o g y, ~} 4700$ KAUST, Thuwal, 23955-6900, Saudi Arabia
}

\section{A R T I C L E I N F O}

\section{Keywords:}

Alexandrium catenella

Massively parallel sequencing

Osaka Bay

Paralytic shellfish poisoning

Plankton assemblages

Species diversity

\begin{abstract}
A B S T R A C T
Since 2002, blooms of Alexandrium catenella sensu Fraga et al. (2015) and paralytic shellfish toxicity events have occurred almost yearly in Osaka Bay, Japan. To better understand the triggers for reoccurring A. catenella blooms in Osaka Bay, phytoplankton community was monitored during the spring seasons of 2012-2015. Monitoring was performed using massively parallel sequencing (MPS)-based technique on amplicon sequences of the 18S rRNA gene. Dense blooms of $A$. catenella occurred every year except in 2012, however, there was no significant correlation with the environmental parameters investigated. Plankton community diversity decreased before and middle of the $A$. catenella blooms, suggesting that the decline in diversity could be an indicator for the bloom occurrence. The yearly abundance pattern of $A$. catenella cells obtained by morphology-based counting coincided with the relative sequence abundances, which supports the effectiveness of MPS-based phytoplankton monitoring.
\end{abstract}

\section{Introduction}

Planktonic microbes, including protozoa, algae, fungi, and small metazoans, are ubiquitous and diverse in marine ecosystems (Jobard et al., 2010; Caron et al., 2012; de Vargas et al., 2015; Yu et al., 2015; Hu et al., 2016; Hirai et al., 2017). These microeukaryotic organisms are important components of marine food webs as predators, producers, decomposers, and parasites, and thus, play key roles in the functioning of marine ecosystems (Azam et al., 1983; Sherr and Sherr, 1994; Duffy and Stachowicz, 2006; Sherr et al., 2011). Minor variations in the structure and composition of these communities may cause changes at different trophic levels (Gamfeldt et al., 2005; Anjusha et al., 2013; Plum et al., 2015; Camarena-Gómez et al., 2018). As most microeukaryotic plankton assemblages are highly susceptible to environmental deterioration and pollution (Smayda, 1998; Stomp et al., 2008), it is necessary to investigate and monitor temporal variations in the biodiversity within their communities to characterize the health of marine ecosystems (Ptacnik et al., 2008; Beaugrand et al., 2010; Johnson et al., 2011; Spilling et al., 2018). Another important aspect of monitoring biodiversity is the detection of harmful algal bloom (HAB) species as their blooms can have a negative influence on several sectors, e.g. aquaculture, tourism, public health, damage to the marine ecosystems (Zingone and Enevoldsen, 2000; Anderson, 2009; Dyson and Huppert, 2010; Berdalet et al., 2016).

Studies on microbial community diversity have traditionally relied on morphology-based identification and quantification done by microscopic observation (e.g. Taylor and Waters, 1982; Balech, 1995; Tomas, 1997; Edler and Elbrächter, 2010; Nishikawa et al., 2010; Wollschläger et al., 2015). Reliable identification of these microorganisms by light microscopy (LM) may be challenging due to small size as well as lack of distinctive and taxonomical rigorousness in morphological characteristics (e.g. Rhodes, 1998; Nübel et al., 1999; John et al., 2005; Aguilera et al., 2006; Galluzzi et al., 2008). Massively parallel sequencing (MPS) is a powerful method enabling detection of species unidentifiable by LM (e.g. Sogin et al., 2006; Caron et al., 2012; Nagai et al., 2017; Gran-Stadniczeñko et al., 2018) and revealing the hidden diversity of microbial communities in environmental samples (Tanabe et al., 2016; Nagai et al., 2016a;b; Dzhembekova et al., 2017;

\footnotetext{
* Corresponding author at: National Research Institute of Fisheries Science, 2-12-4 Fukuura, Kanazawaku, Yokohama, Kanagawa, 236-8648, Japan.

E-mail address: snagai@affrc.go.jp (S. Nagai).
} 

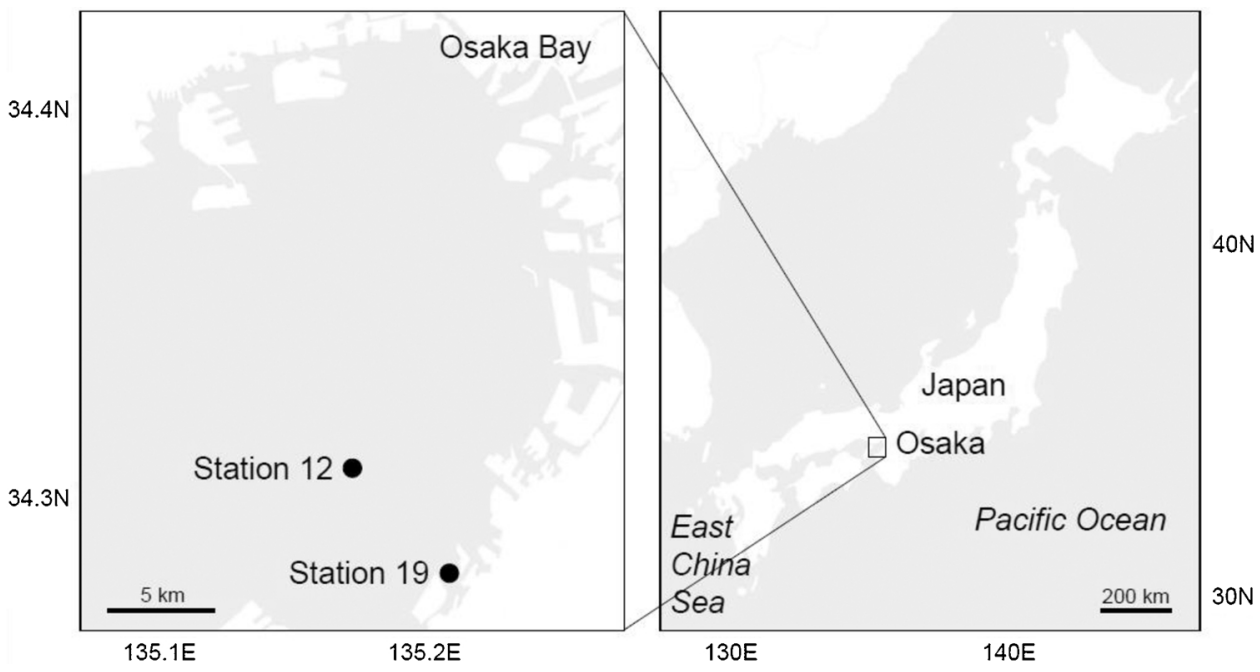

Fig. 1. Sampling stations (Stations 12 and 19) in Osaka Bay, Japan.

Sze et al., 2018).

Effectiveness of MPS to detect many species simultaneously is especially relevant to reveal the presence of HAB species/genera (e.g. Dzhembekova et al., 2017; Elferink et al., 2017; Moreno-Pino et al., 2018; Nagai, 2018) and gather information on their appearances as some species may be present sporadically (Nagai et al., 2017) or during specific seasons (Sildever et al., 2019). This information is prerequisite for monitoring by other molecular methods, e.g. qPCR and microarrays, which are limited by the number of species that can be detected at the same time (Medlin and Orozco, 2017) and by the need for specific primers to detect species of interest from the environmental samples (Garneau et al., 2011; Nagai et al., 2016c; Penna et al., 2013; Ruvindy et al., 2018).

The microalgal genus Alexandrium Halim, 1960 (Dinophyceae, Gonyaulacales) currently contains 34 species (Balech, 1995; MacKenzie and Todd, 2002; Montressor et al., 2004; Guiry and Guiry, 2019), including 12 that are known to produce paralytic shellfish toxins (PSTs) (Anderson et al., 2012; Moestrup et al., 2019), responsible shellfish toxicity and the resulting paralytic shellfish poisoning (PSP) throughout the world (Anderson et al., 2012). To provide an early warning for the fisheries industry and avoid adverse effects on human health, monitoring the temporal variation in the abundance of Alexandrium spp. has become indispensable (Itakura et al., 2002; Weise et al., 2002; Anderson et al., 2005; Shimada et al., 2012; Laanaia et al., 2013; Yamamoto et al., 2013; 2017). In this study, A. catenella sensu Fraga et al. (2015) was monitored in relation to plankton biodiversity and environmental parameters as this toxic dinoflagellate is present in all Japanese coastal waters (Fukuyo, 1985; Sekiguchi et al., 1986; Uchida et al., 1980; Yamamoto et al., 2009) and has become a conspicuous species in southwestern Japan since 1990s (Yamamoto and Yamasaki, 1996; Kotani et al., 1998).

In Osaka Bay, PSTs were first reported in bivalves in the spring of 2002 (Hamano et al., 2002; Yamamoto, 2004). Since then, the growing number of $A$. catenella blooms and PST contamination of bivalves have been observed almost yearly (Yamamoto et al., 2017; Yamamoto and Oikawa, 2017). The appearance of $A$. catenella blooms in southwestern Japan may be related to changes in phytoplankton species diversity. From the late 1970 s to early 1980 s diatoms were the most dominant group causing HABs in the Seto Inland Sea, including Osaka Bay, whereas raphidophytes became significant in the mid-1980s and were replaced by dinoflagellates in 1990s (Yamamoto, 2003). The changes in dominating $\mathrm{HAB}$ species have been explained by the reduction of DIN and DIP concentrations since the 1980s (Yamamoto, 2003; Abo and Yamamoto, 2019). On a shorter perspective, the development of $A$. catenella blooms are also influenced by other factors, as the species has been detected yearly from 2002 to 2016 in Osaka Bay, however, the blooms did not occur every year (Yamamoto et al., 2017). In addition to influence of physical factors, e.g. water column stability (Yamamoto et al., 2002; 2013), reduction in DIP concentrations (Yamamoto et al., 2017) and exhaustion of nutrients by large diatoms resulting in reduced spring bloom intensity (Itakura et al., 2002) have been suggested to contribute to the development of $A$. catenella blooms. This suggests that changes in biodiversity may allow predicting the occurrence of $A$. catenella blooms.

Thus, the aim of this study was to investigate the temporal variation in the diversity of microeukaryotic plankton assemblages to reveal patterns in A. catenella and other phytoplankton species appearance to better understand the triggers for reoccurring A. catenella blooms in Osaka Bay. Weekly sampling to monitor $A$. catenella and other microeukaryotic species in Osaka Bay was conducted from February to May 2012-2015 and analyzed these samples by using an MPS-based technique.

\section{Materials and methods}

\subsection{Sampling and DNA extraction}

Seawater samples were obtained weekly using a 10-m hose (diameter, $25 \mathrm{~mm}$ ) from February to May during 2012-2015 ( $\mathrm{n}=122)$ at two sampling stations (Stations 12 and 19) in Osaka Bay (St. 12, $34^{\circ}$ $30.36^{\prime} \mathrm{N}, 135^{\circ} 16.83^{\prime} \mathrm{E} ; 34^{\circ} 28.20^{\prime} \mathrm{N}$, St.19, $135^{\circ} 19.83^{\prime}$ E), Japan (Fig. 1). The sea surface temperature was measured with a thermometer on-site and the salinity was measured using a salinometer (Digi-auto Model 3-G, Tsurumi Seiki Co. Ltd.) in the laboratory. Water samples for nutrient analysis were collected biweekly and filtered through a GF/C filter. Dissolved inorganic nitrogen (DIN $=\mathrm{NO}_{3}+\mathrm{NO}_{2}+\mathrm{NH}_{4}$ ), phosphate $\left(\mathrm{PO}_{4}\right)$, and silicic acid $\left(\mathrm{Si}(\mathrm{OH})_{4}\right)$ were analyzed using an autoanalyzer (swAAt, BLTEC). Monthly precipitation, number of rainy days, maximum wind speed, and peak gusts in the sampling area (Kankujima station) during February-April of 2012-2015 were downloaded from the official website of the Japan Meteorological Agency (http://www.jma.go.jp/; accessed 10.04.2019).

All the plankton in the samples were trapped by filtering $500 \mathrm{~mL}$ of seawater through $8-\mu \mathrm{m}$ pore-size polycarbonate filters (Nuclepore membrane; GE Healthcare, Tokyo, Japan), followed by their filtration through 1- $\mu \mathrm{m}$ pore-size filters (GE Healthcare). The filters were stored in a deep freezer $\left(-80^{\circ} \mathrm{C}\right)$ until use. For DNA extraction, a 5\% Chelex ${ }^{\circledR}$ suspension (Chelex 100 Molecular Biology Grade Resin; Bio-Rad Laboratories Inc., Richmond, CA) was prepared by dispersing the resin in ultra-pure water (Nagai et al., 2012). For effective DNA extraction 
from plankton components trapped on the filters, the filters were cut in half, placed in 1.5-mL tubes (A.150; Assist; Tokyo, Japan), and $150 \mu \mathrm{L}$ of $5 \%$ Chelex buffer was added. The plankton cells were crushed using a pellet pestle cordless motor (KontesGlass; Vineland, NJ, USA) for $60 \mathrm{~s}$; $350 \mu \mathrm{L}$ of buffer was then added to make up a final volume of $500 \mu \mathrm{L}$. Following this, DNA was extracted by heating the contents of the 1.5$\mathrm{mL}$ tubes at $97^{\circ} \mathrm{C}$ for $20 \mathrm{~min}$ (Tanabe et al., 2016). The DNA extracted from the $8-\mu \mathrm{m}$ and $1-\mu \mathrm{m}$ filters was mixed equally $(50 \mu \mathrm{L}+50 \mu \mathrm{L})$ and used as template DNA.

\subsection{Enumeration of Alexandrium catenella by microscopic observation}

The seawater samples were also used to enumerate the abundance of the PSP-causing dinoflagellate A. catenella as well to compare the relative abundance of $A$. catenella to the relative number of sequences per sample. One liter of seawater was sieved through a $10-\mu \mathrm{m}$ nylon mesh and the plankton components were concentrated until they reached a volume of $10 \mathrm{~mL}$. The abundance of $A$. catenella in $1 \mathrm{~mL}$ of the concentrated seawater was counted by morphology-based observation using an inverted microscope (TE-300, Nikon, Tokyo, Japan).

\subsection{Polymerase chain reaction amplification and 454 pyrosequencing}

A set of universal primer pairs for amplification of the 18S rRNA gene was used to amplify the V7-9 hypervariable regions (SSR-F1, 289, F: TGGAGYGATTTGTCTGGTTDATTCCG; SSR-R1, 772, R: TCACCTA CGG AAACCTTGTTACG) (Tanabe et al., 2016); six-base pair (bp) tags were added to the $5^{\prime}$-end of the primers for recognition of each sample in metagenetic analysis. The amplification reaction was performed using a thermal cycler (PC-808; ASTEC; Fukuoka, Japan) in a reaction mixture $(50 \mu \mathrm{L}$ ) containing $2.0 \mu \mathrm{L}$ template DNA ( $<1 \mathrm{ng}) ; 0.2 \mathrm{mM}$ each of the dNTPs; $1 \times$ PCR buffer; $1.5 \mathrm{mM} \mathrm{Mg}^{2+} ; 1.0 \mathrm{U}$ KOD-Plus-ver. 2 (TOYOBO; Osaka, Japan), which has intensive $3^{\prime} \rightarrow 5^{\prime}$ exonuclease activity; and $1.0 \mu \mathrm{M}$ each of the primers. The PCR cycling conditions were as follows: initial denaturation at $94^{\circ} \mathrm{C}$ for $2 \mathrm{~min}$, followed by 25 cycles with each having periods of $94^{\circ} \mathrm{C}$ for $15 \mathrm{~s}, 56^{\circ} \mathrm{C}$ for $30 \mathrm{~s}$, and $68^{\circ} \mathrm{C}$ for $1 \mathrm{~min}$. PCR amplification was verified by agarose gel electrophoresis. The PCR products were purified using a High-Pure PCR Product Purification Kit (Roche; Basel, Switzerland) and eluted in $35 \mu \mathrm{L}$ of elution buffer following the manufacturer's protocol. Amplified PCR products were quantified using a Qubit 2.0 Fluorometer (Life Technology, Carlsbad, CA, USA) and mixed equally. Amplicon sequencing was performed using the Roche 454 GS-XLR70 Titanium sequencing platform. A 454-pyrosequencing library was constructed using the GS Titanium Rapid Library Preparation Kit (Roche Diagnostics; Branford, CT, USA); pyrosequencing was then performed using a Roche 454 GS FLX + sequencer according to the manufacturer's protocol (Roche Diagnostics; Branford, CT, USA).

\subsection{Treatment processes for the MPS data and operational taxonomic unit- pick up}

Nucleotide sequences were demultiplexed based on 5' MID-tag and primer sequences ( $\mathrm{MID}=$ multiplex identifier). As the sequencing adapters were ligated after the PCR, each sample sequence contained sequences for both strands. Both strands shared the same MID-tag sequence, but the $5^{\prime}$ primers were distinct, therefore, different strand sequences were also sorted. The sequences containing (a) $>1$ bp mismatch in the MID-tag, (b) $>2$ bp mismatches in the primer sequences, (c) $\mathrm{N}$ in both the MID-tag and primer sequences, and (d) monopolymers longer than $9 \mathrm{bp}$ were trimmed from the sequences at both ends. The $3^{\prime}-$ tails with an average quality score of less than 25 at the end of the last 50-bp window were also trimmed from each sequence. Sequences longer than $430 \mathrm{bp}$ were truncated to $430 \mathrm{bp}$ by trimming their $3^{\prime}$-tails. Trimmed sequences shorter than 400 bp were filtered out. Subsequently, each sequence was aligned with template sequences using multiple alignments as described previously (SILVA release 111, http://www.arb-silva.de/), and only the sequences that were aligned in appropriate positions were extracted. The demultiplexing, trimming, filtering, and multiple alignment processes were performed using the screen.seqs, trim.seqs, filter.seqs, and align.seqs, commands, respectively, in Mothur based on the SOP (http://www.mothur.org/wiki/454_ $\mathrm{SOP})$. The reverse strand sequences were converted to their reversecomplement sequences. Erroneous and chimeric sequences were detected and removed using pre.cluster (diffs $=4$ ) and chimera.uchime ( $\operatorname{minh}=0.1 ; \quad$ http://drive5.com/usearch/manual/uchime_algo.html) commands in Mothur, respectively. In addition, singletons were removed. The forward strand sequences and reverse-complement sequences of the reverse strand for each variable region were separately processed. The remaining sequences were assembled using the clmergeclass command in Claident (Tanabe, 2012a) and Assams-assembler v0.1.2013.07.19 (Tanabe, 2012b) with sequence identity thresholds of 0.99 ( 0.01 distance radius in sequence space) and a minimum overlap length of $100 \mathrm{bp}$. Sequence assembly of homologous amplicon sequences by software, Claident, and Assams, is equivalent to complete linkage clustering, except that the resulting sequences are not representative sequences but are only consensus sequences. The contig sequences were counted as operational taxonomic units (OTUs) and used for the taxonomic identification analysis given in the next subsection. Demultiplexed, filtered, but untrimmed sequence data were deposited in the DDBJ Sequence Read Archive under accession no. PRJDB4580.

\subsection{Taxonomic identification of the OTUs}

The selected OTUs were taxonomically identified as follows: for the BLAST search, a subset of NCBI non-redundant nucleotides (NT) consisting of sequences that satisfied the below-mentioned conditions was prepared. The sequences used to identify OTUs were downloaded from the GenBank based on the following search criteria: "ribosomal", "rrna" or "rdna", and the search excluded keywords associated with "metagenome", "uncultured" and "environmental". The sequences of retrieved GenBank IDs were downloaded from the nucleotide database at the NCBI FTP server on March 11, 2019, and were used to construct a template sequence database. Subsequently, the taxonomic identification for each OTU was performed using a BLAST search (Cheung et al., 2010) in NCBI BLAST + 2.2.26 + (Camacho et al., 2009) with default parameters. The nucleotide subset described above was treated as a database, and all OTU representative sequences were treated as queries. Subsequently, taxonomic information was obtained from the BLAST top bit-score hit for each query sequence. Sequences were clustered to OTUs at $\geq 99.1 \%$ similarity level. The raw OTU reads were normalized by rarefying to 1155 sequence reads to facilitate comparing biodiversity among samples (Weiss et al., 2017).

The relative abundance of OTUs among samples at the supergroup level was compared by counting the number of sequences at each level for the 122 samples. In this study, the supergroups were defined as Alveolata, Amoebozoa, Apusozoa, Archaeplastida, Excavata, Hacrobia, Metazoa, Opisthokonta, Rhizaria, Stramenopila, and Viridiplantae as done by Adl et al. (2005); Burki et al. (2007); Frommolt et al. (2008); Archibald (2009); Hampl et al. (2009); Okamoto et al. (2009), and Sakaguchi et al. (2009).

Presence of harmful algal bloom (HAB) species among the detected OTUs (non-rarefied dataset) was investigated by comparing the list of OTUs associated by a single species against the IOC-UNESCO Taxonomic Reference List of Harmful Micro Algae (Moestrup et al., 2019). The non-rarefied dataset was used to detect the presence of all the toxic $\mathrm{HAB}$ species as rarefying may omit data on the presence of some OTUs (Weiss et al., 2017). Only OTUs with the tophit similarity $>0.99$ were included. For A. catenella, the nomenclature suggested by Fraga et al. (2015) was followed. 


\subsection{Community diversity analysis}

The numbers of shared OTUs among different sampling years (rarefied dataset) were counted and depicted as a Venn diagram by using the "vegan" package (v2.3-1, Oksanen et al., 2019) in R (R Core Team, 2019). Species richness was calculated as the number of OTUs representing community diversity among the assemblages. The Simpson's diversity index was calculated as the proportion of species $i$ relative to the total number of species $\left(P_{i}\right)$ multiplied by the natural logarithm of this proportion $\left(\ln P_{i}\right)$. Simpson's diversity index measures the degree of concentration, when individuals are classified into types, and represents species evenness within the assemblage (Simpson, 1949). The index is calculated as the reciprocal of the sum of the squared $P i$ for all the species. The biodiversity of eukaryotic communities in the samples was evaluated by applying the Bray-Curtis similarity index and visualized by non-metric multidimensional scaling (NMDS) in "vegan". The goodness of fit of the resulting NMDS mapping was assessed by a Shepard diagram (Fig. S1). Biodiversity data from different years and months were separately visualized by NMDS to investigate differences in biodiversity on different temporal scales. Influence of environmental parameters to the variability in biodiversity was investigated by fitting data on water temperature, salinity, $\mathrm{DIN}, \mathrm{PO}_{4}$, and $\mathrm{Si}\left(\mathrm{OH}_{4}\right)$ concentrations in the NMDS plot by envfit function. Differences in biodiversity between the years and months were investigated by PERMANOVA using the Bray-Curtis similarity index and 999 permutations and the assumption for homogeneity of multivariate dispersions was tested by ANOVA (betadisper function in "vegan").

Pearson correlations were calculated between the environmental parameters, microscopic observations, relative abundances of $A$. catenella OTUs detected, number of different OTUs detected and Simpson's index for data from both stations by using the package "psych" (Revelle, 2019 ) in R. Since nutrient data was collected biweekly, the correlation analysis for both stations was performed using two datasets: $\mathrm{n}=26$ (all parameters) and $\mathrm{n}=61$ (nutrient data not included), $P$ value was adjusted for multiple tests by using Bonferroni correction.

To investigate changes in species composition between the years with A. catenella blooms (2013-2015) and no bloom (2012), differences in average relative abundances were calculated for OTUs associated with microalgae (Station 12: $\mathrm{n}=270$, station 19: $\mathrm{n}=273$, Table S1). Changes in 30 OTUs showing the highest differences in abundances were investigated.

\section{Results}

\subsection{Environmental conditions during the survey periods in Osaka Bay}

Temporal variation in environmental conditions, such as monthly precipitation, number of rainy days, and maximum wind speed in the sampling area of Osaka Bay in February-April during 2012-2015 are shown in Table 1. In 2012, the average monthly precipitation and number of rainy days for February-April were greater than in 2013, 2014 and 2015, as well as than the 10-years average (2005-2014). Maximum wind speed and peak gusts were observed in April 2012, suggesting potentially greater vertical mixing of seawater in 2012 than in 2013, 2014, and 2015. Solar radiation time in 2013 was highest and followed by 2014,2012 , and 2015. In this study, water temperatures ranged from $7.5^{\circ} \mathrm{C}$ to $21.7^{\circ} \mathrm{C}$ at the two sampling locations during the survey period and increased steadily from February to April in each year and did not differ greatly among different years (Fig. 2). Salinity ranged from 26.0 to 32.4 during the survey period and decreased several times due to precipitation except for 2013 (Fig. 2). DIN, $\mathrm{PO}_{4}$ and $\mathrm{Si}$ $(\mathrm{OH})_{4}$ concentrations during the survey period were $0.1-25.6 \mu \mathrm{M}$, $0.01-0.73 \mu \mathrm{M}, 0.1-23.5 \mu \mathrm{M}$, respectively. Concentrations of the inorganic nutrients were lower in 2013 and 2014 than in 2012 and 2015 (Fig. 3).

\subsection{Detected community diversity}

The number of sequences after the removal of sequence errors and chimeras varied from 1155 to $62,783(19,042 \pm 12,208$, mean \pm SD) (data not shown). In the frequency distribution of the top BLAST hit similarity, $34.32 \%$ of the data scored 1.0 for the highest similarity with the reference sequences, and $63.57 \%$ scored $>0.98$. In total, 571 OTUs in plankton assemblages from 122 samples collected at two localities were detected (Table S2). Out of all the identified OTUs in the nonrarefied dataset, 13 were associated with the toxic $\mathrm{HAB}$ species (Moestrup, et al. 2019), including four Alexandrium species: A. andersonii, A. catenella, A. minutum, and A. pacificum. (Table S2). In addition, two non-toxic Alexandrium species (A. insuetum and A. leei) were also detected. The detection limit of MPS-based monitoring of $A$. catenella was $1 \mathrm{pg}$, which is equivalent to 50 copies of rRNA genes (Nagai et al., 2016c), indicating that the technique is sufficiently sensitive for monitoring $A$. catenella.

The rarefied dataset contained 494 OTUs (Table S3), of which 209 OTUs (42.31\%) were shared among four years, however, $21(4.25 \%)$, $14(2.83 \%), 41(8.29 \%)$ and 27 OTUs (5.46\%) were detected only in 2012, 2013, 2014, and 2015, respectively (Fig. 6). From all the OTUs detected (571, based on the non-rarefied dataset) 316 (55.34\%) were identified as a single species, e.g. 69 as dinoflagellates, 30 as diatoms, 68 as zooplankton, 38 as ciliates (Table S2). Species richness with rarefaction was $62-119$ OTUs (92 \pm 16 ), 31-127 (79 \pm 28$), 16-105$ $(54 \pm 21), 21-108(57 \pm 23)$, in $2012,2013,2014$, and 2015 , respectively (Fig. 4). Simpson's index ranged from 0.48 to 0.95 $(0.82 \pm 0.10), \quad 0.23$ to $0.96 \quad(0.74 \pm 0.21), \quad 0.17$ to 0.94 $(0.64 \pm 0.20)$ and, 0.14 to $0.94(0.61 \pm 0.20)$ in 2012, 2013, 2014, and 2015, respectively (Fig. 4). Samples in which the index was smaller than 0.5 was $3.12 \%$ ( 1 out of 32 samples), $18.17 \%$ (6/32), $21.87 \%$ (7/ 32 ), and $37.5 \%(12 / 32)$ in $2012,2013,2014$, and 2015 , respectively.

The NMDS analysis based on Bray-Curtis index ( $\mathrm{k}=3$, stress 0.17 ), revealed that samples collected in 2012 clustered closer together in comparison to those collected in 2013, 2014, and 2015 (Fig. 5A). Conversely, the dispersed distribution of the samples collected in 2013, 2014, and 2015suggested larger differences in the eukaryotic biodiversity among the samples, which is also visible from the Simpson's diversity index (Fig. 4). DIN $(P=0.020), \mathrm{PO}_{4}(P=0.009), \mathrm{Si}\left(\mathrm{OH}_{4}\right)(P$ $=0.029)$, and water temperature $(P=0.001)$ contributed significantly to the variability in biodiversity, whereas the influence of salinity was not significant $(P=0.051)$ (Fig. 5A, B). The biodiversity in sampled communities was significantly different between months and years $(\mathrm{P}<0.001)$, however, the homogeneity of multivariate dispersions was only met for dataset based on months $(P=0.19)$, but not for the dataset based on years $(P=0.03)$. Thus, it is not certain if the significant difference in biodiversity between the years reflects true dissimilarity between the years or differences in biodiversity within the years compared (Anderson et al., 2006).

\subsection{Detection of the toxic dinoflagellate Alexandrium catenella}

The abundance of $A$. catenella, the main causative species behind PSP in Osaka Bay, was enumerated using morphology-based observations from February to May of 2012 to 2015 (Fig. 7, left). Dense blooms of $A$. catenella in Osaka Bay occurred in 2013, 2014 and 2015, but not in 2012. The highest abundance at the two sampling locations was 833; 10,080; 452,670, and 10,821 cells $\mathrm{L}^{-1}$ in 2012 (May 7), 2013 (April 16), 2014 (April 15), and 2015 (March 24), respectively. The temporal variation in the relative sequence abundance of the OTU associated with $A$. catenella displayed a similar pattern with the number of cells detected by light microscopy (Fig. 7, right). Before and middle of the $A$. catenella blooms in 2013, 2014 and 2015, the community diversity of the plankton assemblage in Osaka Bay decreased based on Simpson's index (Fig. 4). The average abundance of top 30 OTUs associated with microalgae top showing the largest change in average abundance 
Table 1

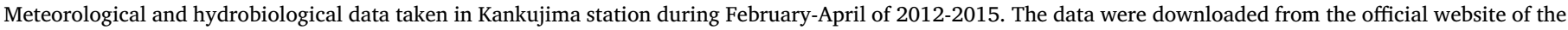
Japan Meteorological Agency (available online from http://www.jma.go.jp/).

\begin{tabular}{|c|c|c|c|c|c|c|}
\hline Year & Month & Precipitation (mm) & Raining day & Solar radiation time (hour) & Maximun wind speed (m s-1) & Peak gust (m s-1) \\
\hline \multirow[t]{4}{*}{2012} & February & 107.5 & 10.0 & 104.4 & 13.6 & 19.0 \\
\hline & March & 104.5 & 9.0 & 152.9 & 16.1 & 21.6 \\
\hline & April & 79.0 & 11.0 & 200.1 & 24.7 & 31.9 \\
\hline & February-April & 291.0 & 30.0 & 457.4 & & \\
\hline \multirow[t]{4}{*}{2013} & February & 80.0 & 11.0 & 139.5 & 14.9 & 21.1 \\
\hline & March & 68.5 & 6.0 & 197.0 & 19.4 & 24.7 \\
\hline & April & 65.0 & 9.0 & 211.2 & 16.7 & 22.1 \\
\hline & February-April & 213.5 & 26.0 & 547.7 & & \\
\hline \multirow[t]{4}{*}{2014} & February & 48.5 & 7.0 & 112.3 & 11.9 & 15.9 \\
\hline & March & 137.0 & 11.0 & 180.9 & 16.4 & 23.1 \\
\hline & April & 70.0 & 8.0 & 201.3 & 14.3 & 19.0 \\
\hline & February-April & 255.5 & 26.0 & 494.5 & & \\
\hline \multirow[t]{4}{*}{2015} & February & 17.0 & 5.0 & 124.4 & 14.8 & 19.0 \\
\hline & March & 157.5 & 11.0 & 163.2 & 14.7 & 23.7 \\
\hline & April & 95.0 & 14.0 & 142.6 & 17.6 & 22.6 \\
\hline & February-April & 269.5 & 30.0 & 430.5 & & \\
\hline 2005-2014 average (sd) & February-April & $232.8(74.0)$ & $27.2(4.4)$ & & & \\
\hline
\end{tabular}

between 2012 (no A. catenella bloom) and 2013-2015 (A. catenella blooms) indicated that at both stations the highest number of OTUs showing a decrease and increase compared to 2012 were associated with dinoflagellates, whereas second largest decrease at both stations was displayed by OTUs associated with diatoms (Fig. 8 A, B). Majority of the OTUs displaying the largest change were same at both stations, however, 9 OTUs differed between the stations (Fig. 8 A, B).

\subsection{Correlations between environmental parameters and biological data}

Of all the abiotic and biotic parameters investigated, statistically significant $(\mathrm{P}<0.05)$ positive relationship was detected between the number of OTUs detected and Simpson's index, $\mathrm{PO}_{4}$ and $\mathrm{Si}(\mathrm{OH})_{4}$, and $\mathrm{PO}_{4}$ and DIN concentrations at both stations (Table 2). Statistically significant $(\mathrm{P}<0.05)$ positive relationship was also detected between
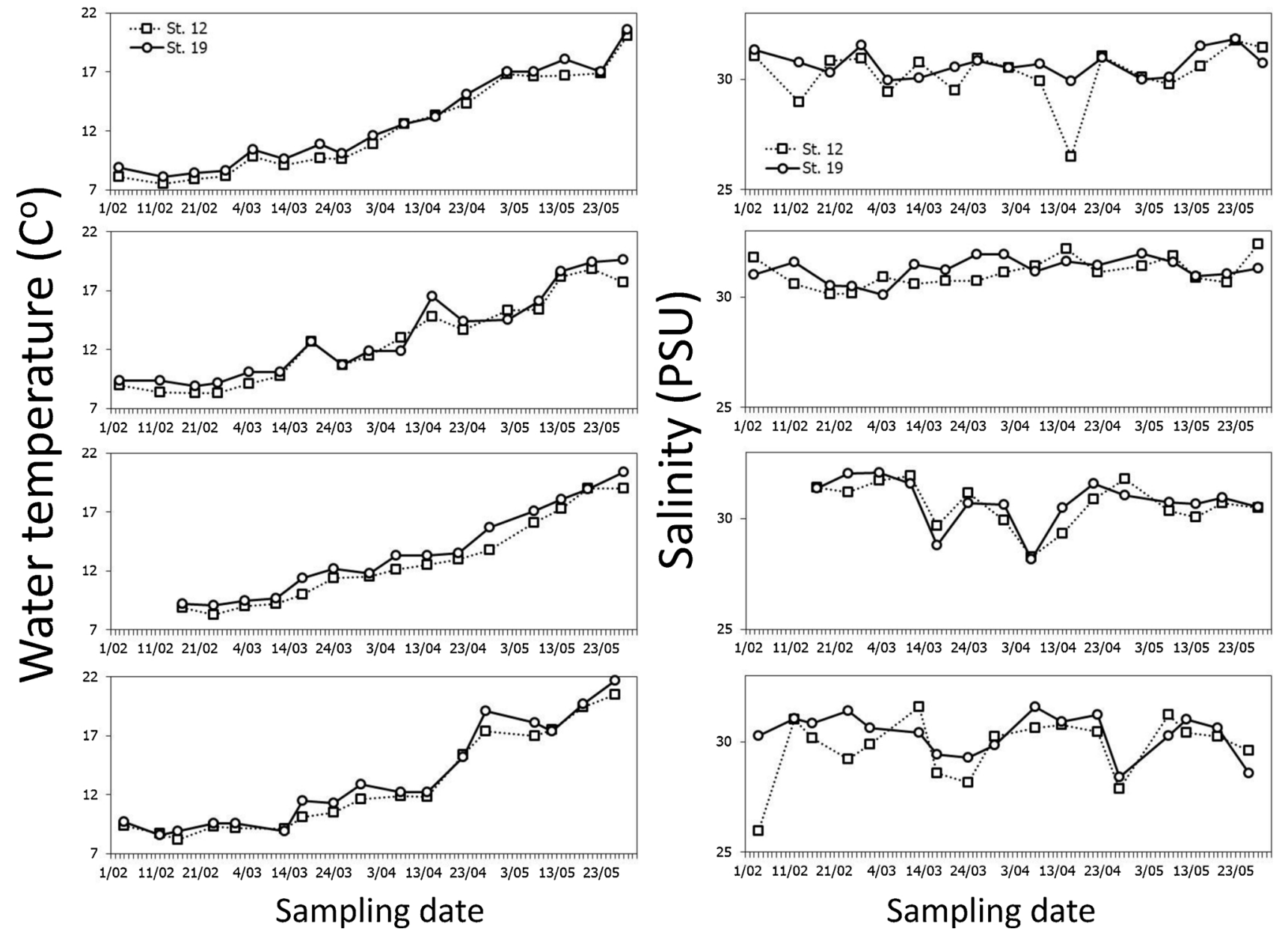

\section{Sampling date}

Fig. 2. Changes of water temperature and salinity during the monitoring from February to May in 2012-2015 at two localities in Osaka Bay. The x-axis shows dates (day/month). 

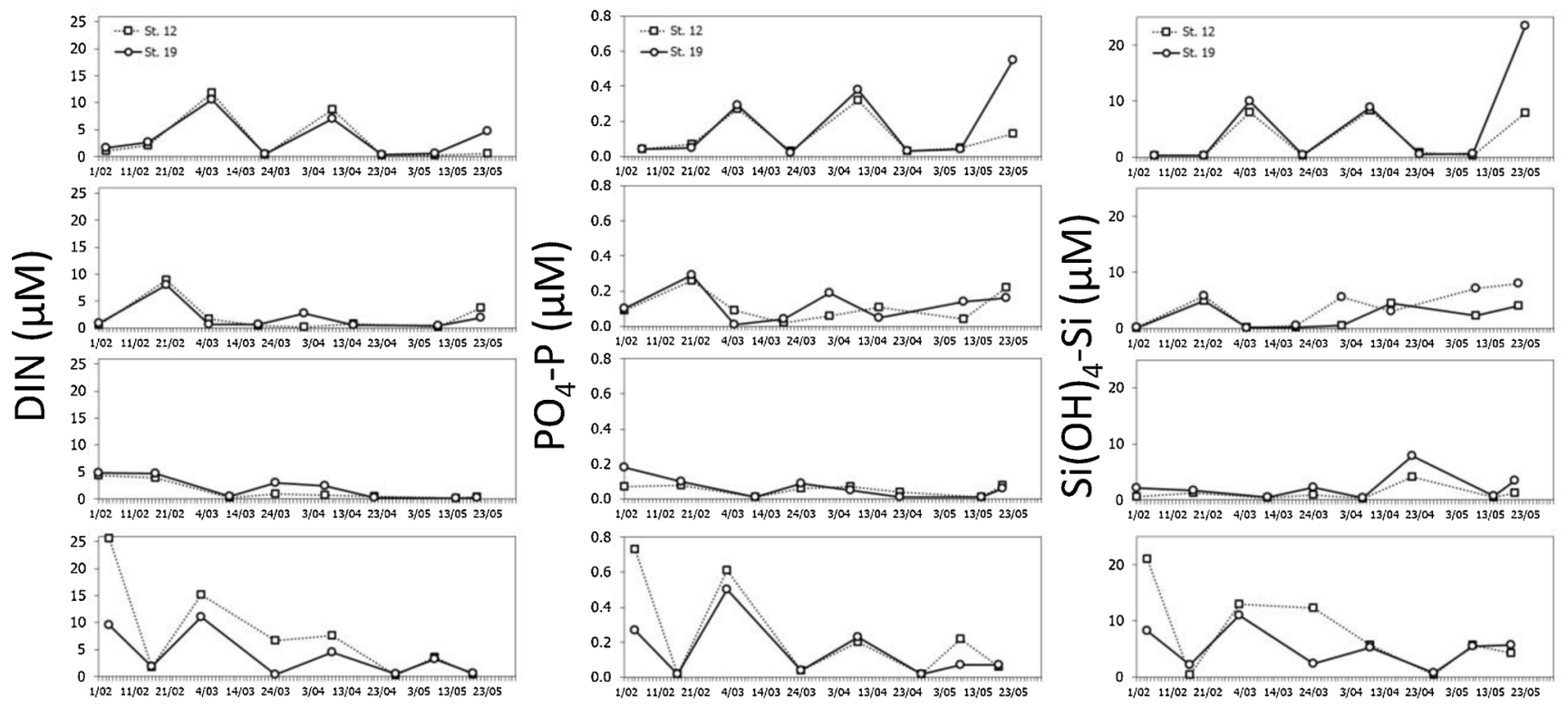

\section{Sampling date}

Fig. 3. Changes of dissolved inorganic nitrogen ( $\left.\mathrm{DIN}=\mathrm{NO}_{3}+\mathrm{NO}_{2}+\mathrm{NH}_{4}\right)$, phosphate $\left(\mathrm{PO}_{4}-\mathrm{P}\right)$, and silicic acid $\left(\mathrm{Si}(\mathrm{OH})_{4}\right.$-Si) concentrations during the monitoring from February to May in 2012-2015 at two localities in Osaka Bay. The x-axis shows dates (day/month).

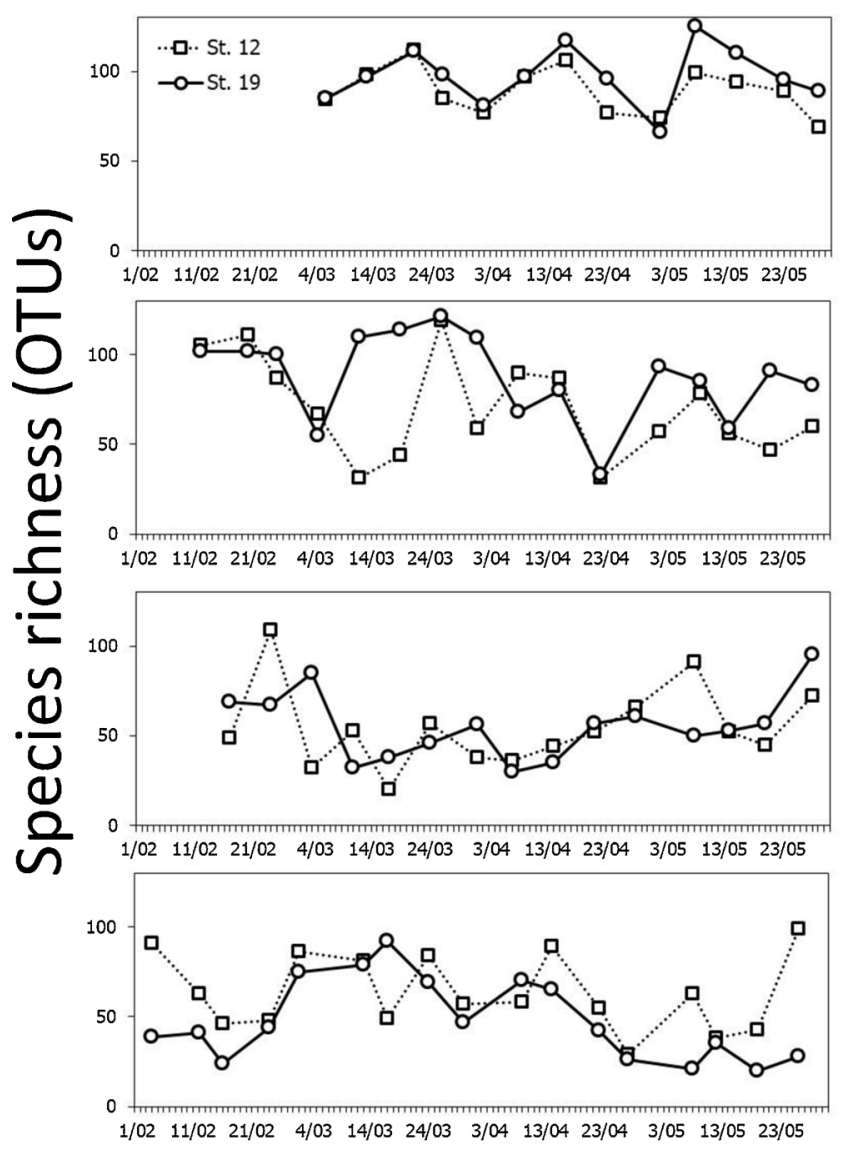

Sampling date

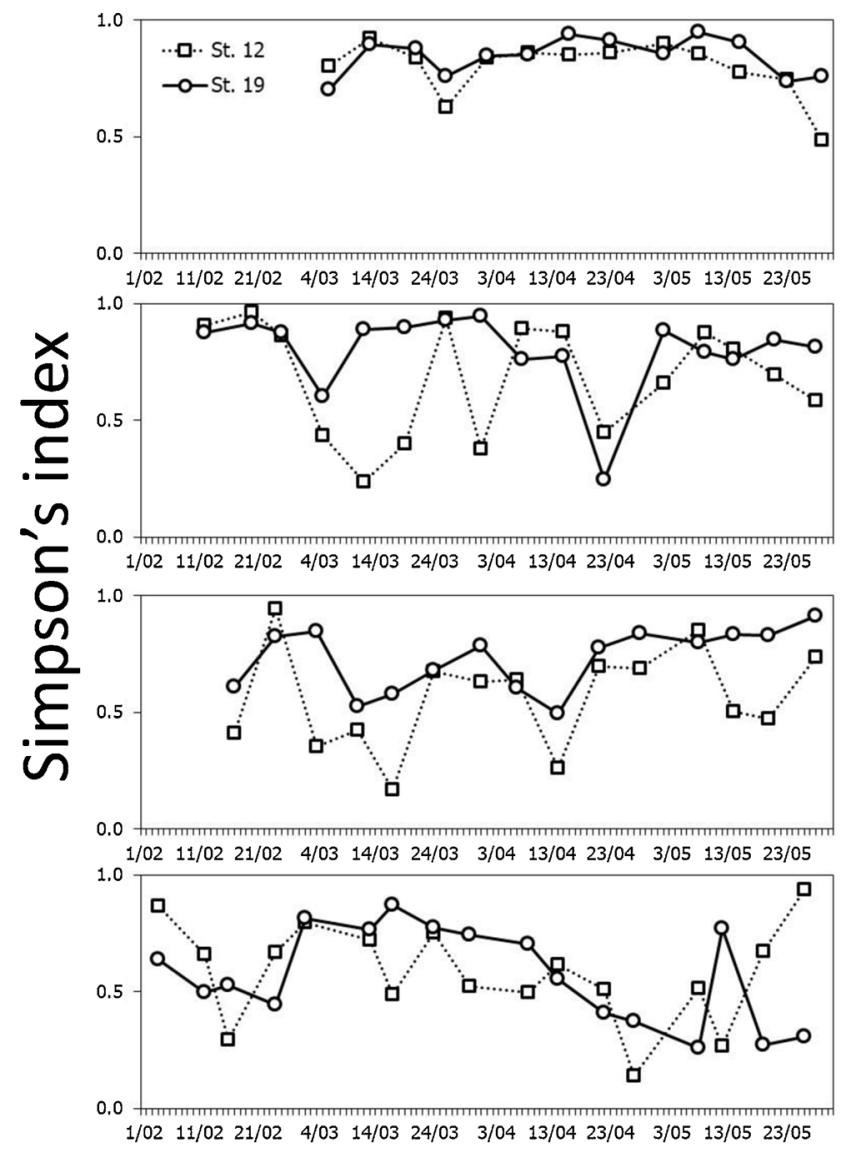

Sampling date

Fig. 4. Temporal variations in community diversity indices at two localities in Osaka Bay from February to May during 2012-2015. Left, Species richness (the numbers of OTUs); Right, Simpson's index (species evenness). The x-axis shows dates (day/month). 

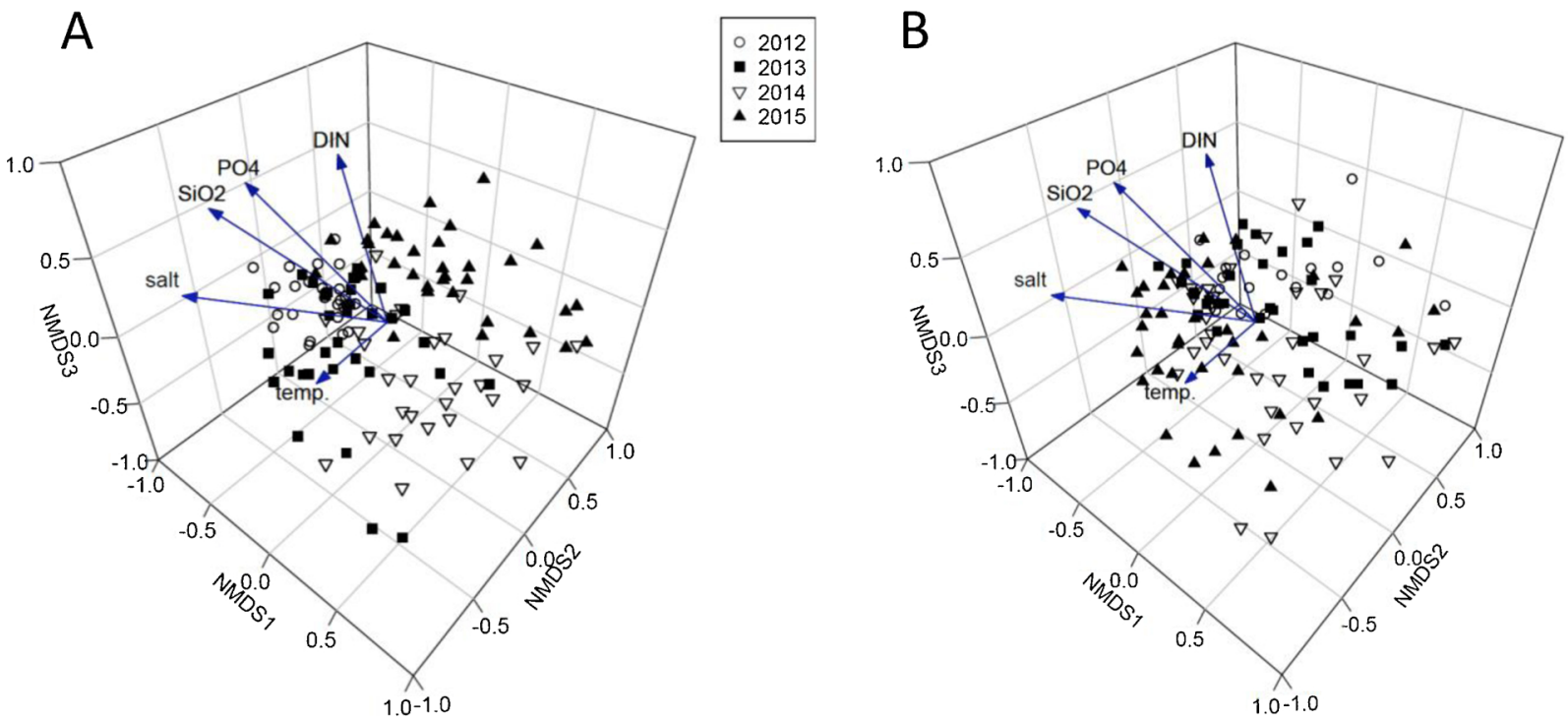

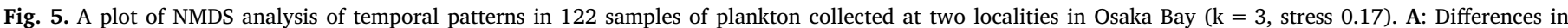

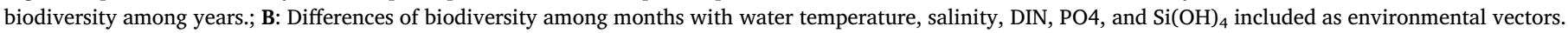

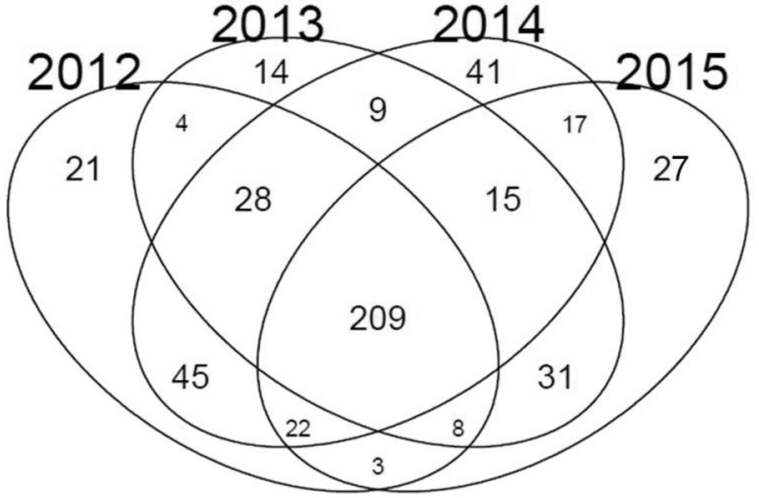

Fig. 6. A Venn diagram showing the number of shared OTUs obtained by the MPS-based monitoring in the 122 seawater samples at two localities in Osaka Bay.

$\mathrm{Si}(\mathrm{OH})_{4}$ and DIN concentrations at station 12 and between $A$. catenella relative abundances detected by MPS and abundances obtained by LM at station 19. A statistically significant relationship between A. catenella abundances obtained by the two methods was also detected at station 12 based on the reduced dataset $(n=26$, data not shown). No statistically significant relationships were detected between other parameters (Table 2).

\section{Discussion}

Alexandrium catenella blooms were detected in 2013-2015 by LM and MPS, whereas no bloom was recorded in 2012, although the presence of the species was confirmed by both methods. The plankton species diversity decreased before and middle of the A. catenella blooms in 2013, 2014 and 2015, potentially indicating that the presence of other species, may influence the development blooms of $A$. catenella in Osaka Bay. In general, both methods displayed a similar pattern in $A$. catenella appearance, which was further supported by a statistically significant $(\mathrm{P}<0.05)$ correlation between the cell abundances and relative sequence read abundances.

\subsection{Patterns in A. Catenella appearance and blooms}

In Osaka Bay, A. catenella vegetative cells are present from February to May (Yamamoto et al., 2017). The seasonal appearance of this species in the Seto Inland Sea is controlled by bottom and surface water temperatures: high cyst germination success at $10-15^{\circ} \mathrm{C}$ (DecemberApril; Itakura and Yamaguchi, 2001) and vegetative cells present in the water column until the surface water temperature reaches around $20^{\circ} \mathrm{C}$ (Itakura et al., 2002; Yamamoto et al., 2017) with the highest encystment rate at $14^{\circ} \mathrm{C}$ (Nagai et al., 2004). In this study, blooms of $A$. catenella were recorded in March and April during 2013-2015 although the species was also present in 2012, and the vegetative cells disappeared when water temperature exceeded $17^{\circ} \mathrm{C}$. Similarly to a previous study from Hiroshima Bay (Itakura et al., 2002), no statistically significant correlation could be detected between temperature and $A$. catenella cell/sequences abundances. Thus, although the temperature is an important for facilitating the germination of $A$. catenella cysts and for bloom termination, the bloom development is potentially controlled by other factors. In 2012, the wind speed and average precipitation were higher than in other years investigated, generating higher turbulence in the surface layer, that generally hampers dinoflagellate blooms (Margalef et al., 1979; Therriault et al., 1985; Uchida et al., 1998). The importance of water column stability to the development and continuation of $A$. catenella blooms has been also indicated in previous studies (Fauchot et al., 2008; Yamamoto et al., 2002; 2011; 2013; Weise et al., 2002). In addition, low spring bloom intensity due to decreased nutrient concentrations has also suggested to contribute to the occurrence of A. catenella blooms in the Seto Inland Sea (Itakura et al., 2002; Yamamoto et al., 2017). Unfortunately, no statistically significant relationship between nutrient concentrations and cell abundances/relative $A$. catenella sequence abundances could be detected in this study. This may be related with the lower number of nutrient samples available $(n=26)$, compared to the previous study reporting statically significant negative correlations between nutrient concentrations and $A$. catenella cell abundances (Itakura et al., 2002; $\mathrm{n}=67$ ). At the same time, the nutrient concentrations were generally lower in 2013 and 2014 (bloom) compared to 2012 (no bloom). Although in 2015 (bloom) the nutrient concentrations were generally similar or even higher than in 2012, the concentrations were reduced prior the A. catenella bloom, coinciding with the suggested pattern (Itakura et al., 2002; Yamamoto et al., 2017). Low nutrient levels may potentially be explained by the reduced freshwater input, e.g. lower precipitation in 2013-2014, or by the presence of large diatoms prior spring bloom, exhausting the inorganic nutrients (Nagai et al., 1996; Itakura et al., 2002).

As A. catenella can utilize dissolved organic phosphorous (Oh et al., 

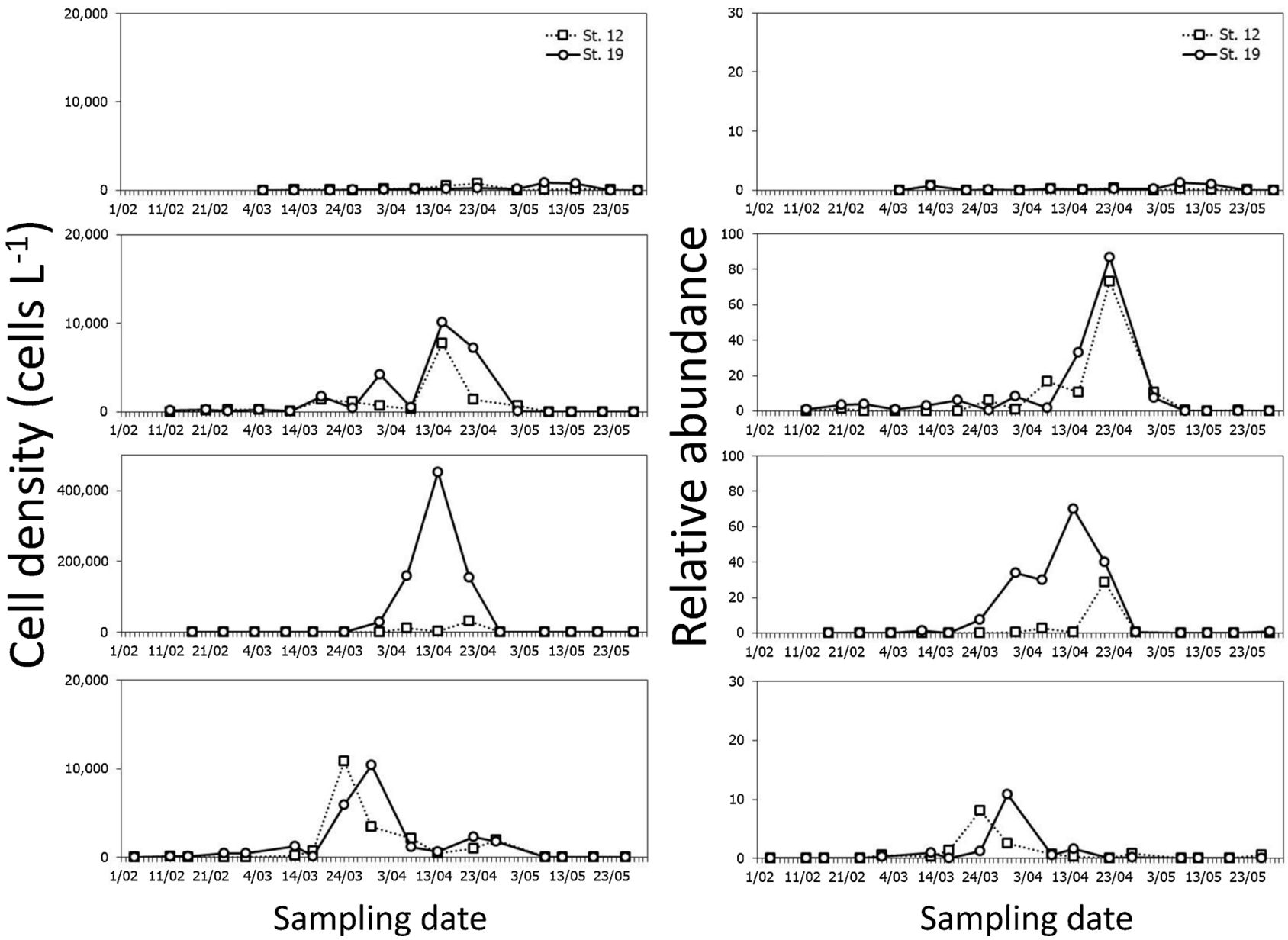

\section{Sampling date}

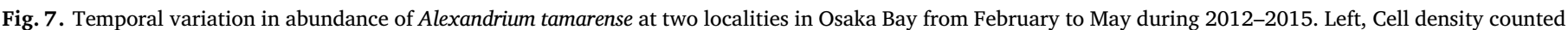

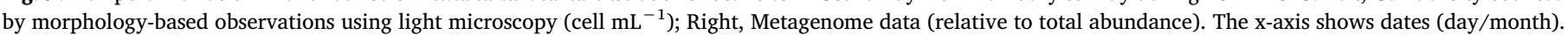

2002) and perform vertical migration (MacIntyre et al., 1997; Fauchot et al., 2005; Yamamoto et al., 2010), the lower nutrient concentrations observed during A. catenella blooms (Itakura et al., 2002) may give the species an advantage over competitors such as fast-growing diatoms (Itakura et al., 2002; Yamamoto et al., 2017; Natsuike et al., 2018). This is further supported by the reduction in average relative sequence abundances of OTUs associated with diatoms in 2013-2015 compared to 2012. Unfortunately, the change in the abundances of diatoms and dinoflagellates cannot be directly compared based on the relative sequence abundances as it may be influenced by the variations in copy number in different groups (e.g. Zhu et al., 2005; Gran-Stadniczeñko et al., 2018) and there is no phytoplankton community composition data obtained by light microscopy available from the sampling occasions. At the same time, diatom blooms generally display high species diversity (Guillard and Kilham, 1977; Smayda, 1980) compared to dinoflagellate blooms (Smayda and Reynolds, 2003) and thus the decline in species diversity detected during 2013-2015 may be regarded as a potential indicator for $A$. catenella bloom development in Osaka Bay. As a future perspective, machine-learning and an association study using data-mining to detect association rules related to the species increase and decrease based on MPS data may help to reveal patterns between species/groups abundance and diversity (e.g. A. catenella and diatoms) and allow prediction of blooms based on community composition data (Cordier et al., 2018; Asano et al., 2019)

\subsection{Massively parallel sequencing approach for phytoplankton monitoring}

Massively-parallel sequencing has become a popular method for detecting protistan diversity and species richness in marine and freshwater ecosystems (e.g. Xiao et al., 2014; de Vargas et al., 2015). MPS technologies deliver high-throughput performance and allow the detection of several hundreds of OTUs (e.g. Tanabe et al., 2016; Nagai et al., 2016a;b; Hu et al., 2016; Elferink et al., 2017; Piredda et al., 2018). The significant advantage of applying MPS-based technology for monitoring of eukaryotic species is its great potential to identify species by genetic information, in particular, the species that are indistinguishable by morphology-based observation using LM (e.g. John et al., 2005; Lelong et al., 2012). Although, the OTU relative abundances do not reflect the number of cells directly (Egge et al., 2013; Weber and Pawlowski, 2013), they may give an overall impression of species/classes relative abundances (Giner et al., 2016; Eiler, et al. 2017; Gran-Stadniczeñko et al., 2017). In addition, when combined with LM counts, the relative sequences abundances may provide a semiquantitative estimate of cell abundances, especially relevant for morphologically similar species, e.g. Pseudo-nitzschia sp. (Nagai et al., 2017). In this study, the relative sequence abundances of the OTU associated with $A$. catenella obtained by MPS displayed a similar pattern with the cell abundances from LM counts.

Interestingly, for station 12 the statistically significant $(\mathrm{P}<0.05)$ correlation was only detected in the reduced datset $(n=26)$. First, it was regarded to result from the rarefiying procedure that randomly omits some sequencing data to normalize library sizes (McMurdie and Holmes, 2014). However, the total sequence abundances of the OTU related with $A$. catenella also did not display a statistically significant correlation with the cell abundances obtained by LM (data not shown) and thus the influence of rarefying does not explain the finding. As 
Class

Dinophyceae Dinophyceae Dinophyceae Bacillariophyceae Dictyochophyceae Bacillariophyceae Dinophyceae Bacillariophyceae Dinophyceae Bacillariophyceae Telonemea Dinophyceae Bacillariophyceae Cryptophyceae Cryptophyceae Dinophyceae Dinophyceae Dinophyceae Bacillariophyceae Raphidophyceae Dinophyceae Dinophyceae Dinophyceae Dinophyceae Dinophyceae Dinophyceae Bacillariophyceae Dinophyceae Dinophyceae Dinophyceae

Class Dinophyceae
Dinophyceae Bacillariophyceae Dinophyceae Dictyochophyceae

Dinophyceae Dinophyceae

Raphidophyceae Bacillariophyceae Telonemea Bacillariophyceae Cryptophyceae Bacillariophyceae Prymnesiophyceae Dinophyceae Bacillariophyceae Pyramimonadophyceae

Dinophyceae

Dinophyceae

Bacillariophyceae

Bacillariophyceae

Raphiodophyceae

Dinophyceae

Dinophyceae

Dinophyceae

Dinophyceae

Dinophyceae

Dinophyceae

Dinophyceae

Dinophyceae

Species

Gyrodinium rubrum

Warnowia sp.

Dinophyceae sp.

Skeletonema sp.

Pseudochattonella verruculosa

Thalassiosira nordenskioeldii

K.veneficum / K. mikimotoi

Pseudo-nitzschia pungens*

Yihiella yeosuensis*

Pseudo-nitzschia americana

Telonema antarcticum

Islandinium tricingulatum

Chaetoceros sp.

Teleaulax sp*

Teleaulax amphioxeia*

Scrippsiella sp.

Gyrodinium of. gutrula

Gymnodinium smaydae

T.proschkinae / Thalassiosira sp.

Heterosigma akashiwo

Oodinium pouchetii *

Prorocentrum sp.

Gymnodinium simplex

Spiniferites ramosus

Biecheleria sp.

Noctiluca scintillans

Leptocylindrus danicus

Heterocapsa rotundata

H. rotundata / G. spirale

Alexandrium catenella

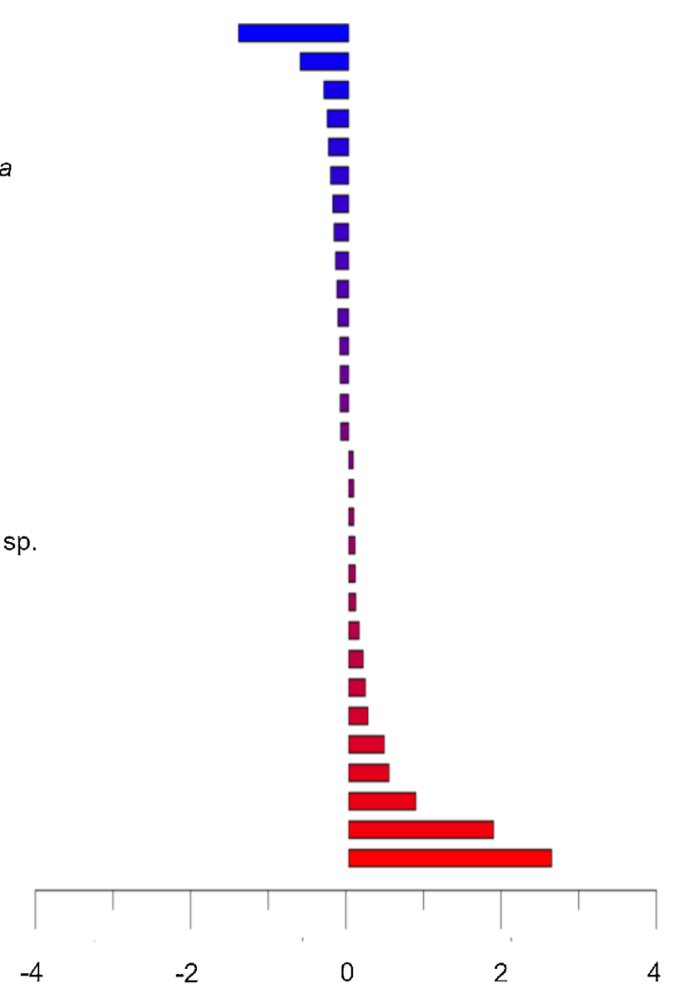

Abundance ${ }^{*} 100$

\section{Species}

Gyrodinium rubrum

Warnowia sp.

Skeletonema sp

Dinophyceae sp.

Pseudochattonella verruculosa

$K$.veneficum $/ K$. mikimotoi

Gymnodinium sp.

Psammamonas australis

Chaetoceros sp.

Telonema antarcticum

Thalassiosira nordenskioeldii

T. amphioxeia / Cryptophyta sp. ${ }^{*}$

Pseudo-nitzschia americana

Chrysochromulina simplex *

Islandinium tricingulatum

Thalassiosira sp.

Pyramimonas australis

Gymnodinium smaydae

Gyrodinium cf. gutrula

T. proschkinae / Thalassiosira sp.

Leptocylindrus danicus

Heterosigma akashiwo

Gymnodinium simplex

Biecheleria sp.

Prorocentrum sp.

Noctiluca scintilians

Spiniferites ramosus

Heterocapsa rotundata

Alexandrium catenella

H. rotundata / G. spirale
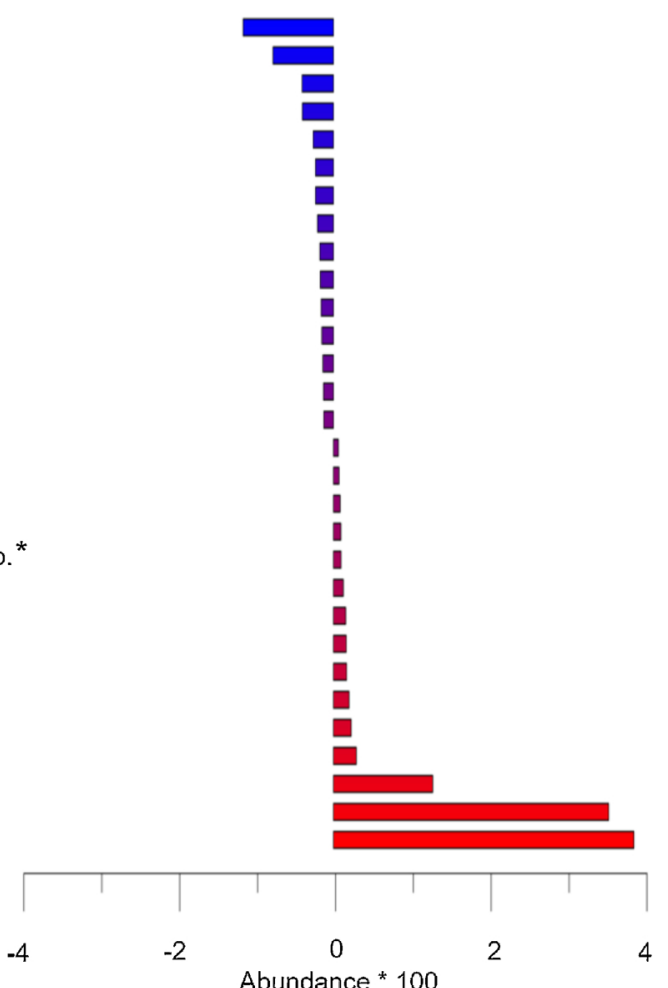

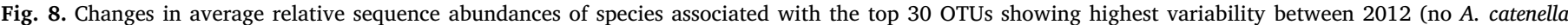

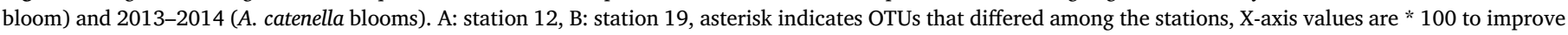
readability, negative values indicate a decrease and positive values show an increase in 2013-2014 compared to 2012. 
Table 2

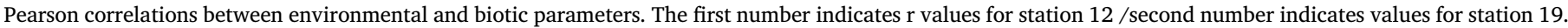

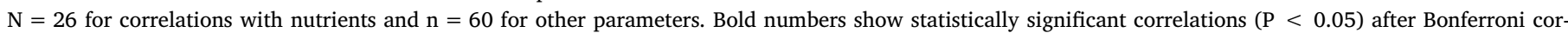

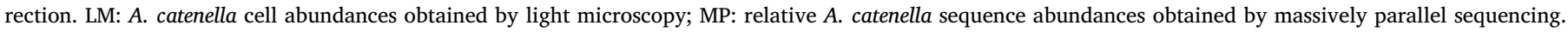

\begin{tabular}{|c|c|c|c|c|c|c|c|c|c|}
\hline & Temperature & Salinity & LM & MPS & Nr. of OTUs & Simpson's index & $\mathrm{PO}_{4}$ & $\mathrm{Si}(\mathrm{OH})_{4}$ & DIN \\
\hline Temperature & & $0.11 /-0.13$ & $-0.03 /-0.01$ & $0.02 /-0.001$ & $-0.18 /-0.19$ & $-0.003 /-0.12$ & $-0.19 /-0.10$ & $-0.14 / 0.15$ & $-0.39 /-0.44$ \\
\hline Salinity & $0.11 /-0.13$ & & $-0.08 /-0.11$ & $0.12 / 0.04$ & $-0.09 / 0.34$ & $-0.04 / 0.26$ & $-0.49 / 0.23$ & $-0.52 / 0.33$ & $-0.61 /-0.04$ \\
\hline LM & $-0.03 /-0.01$ & $-0.08 /-0.11$ & & $0.37 / \mathbf{0 . 6 7}$ & $-0.17 /-0.22$ & $0.01 /-0.17$ & $-0.17 /-0.20$ & $0.07 /-0.03$ & $-0.12 /-0.13$ \\
\hline MPS & $0.02 / 0.001$ & $0.12 / 0.04$ & $0.37 / \mathbf{0 . 6 7}$ & & $-0.15 /-0.26$ & $-0.03 /-0.28$ & $-0.13 /-0.22$ & $0.08 /-0.06$ & $-0.11 /-0.19$ \\
\hline Nr. of OTUs & $-0.18 /-0.19$ & $-0.09 / 0.34$ & $-0.17 /-0.22$ & $-0.15 /-0.26$ & & $0.82 / 0.81$ & $0.46 / 0.28$ & $0.44 / 0.14$ & $0.45 / 0.11$ \\
\hline Simpson's index & $-0.003 /-0.12$ & $-0.04 / 0.26$ & $0.01 /-0.17$ & $-0.03 /-0.28$ & $0.82 / 0.81$ & & $0.38 / 0.19$ & $0.45 / 0.04$ & $0.34 / 0.01$ \\
\hline $\mathrm{PO}_{4}$ & $-0.19 /-0.10$ & $-0.49 / 0.23$ & $-0.17 /-0.20$ & $-0.13 /-0.22$ & $0.46 / 0.29$ & $0.38 / 0.19$ & & $0.83 / 0.86$ & $0.93 / 0.75$ \\
\hline $\mathrm{Si}(\mathrm{OH})_{4}$ & $-0.14 / 0.15$ & $-0.51 / 0.33$ & $0.07 /-0.03$ & $0.08 /-0.06$ & $0.44 / 0.14$ & $0.45 / 0.04$ & $0.83 / 0.86$ & & $0.86 / 0.50$ \\
\hline DIN & $-0.39 /-0.44$ & $-0.61 /-0.04$ & $-0.12 /-0.13$ & $-0.11 /-0.19$ & $0.45 / 0.11$ & $0.38 / 0.01$ & $0.93 / 0.75$ & $0.86 / 0.50$ & \\
\hline
\end{tabular}

another aspect, usage of Bonferroni correction to account for multiple testing was considered as this method is conservative and increases the likelihood of rejecting significant differences (Perneger, 1998). However, this was not the cause as other adjustments (Holm, Hochberg, Hommel, Benjamin-Hochberg) applied to the same dataset resulted also in statistically not significant result, except for Benjamin-Hochberg adjustment. Potential misidentification of $A$. pacificum as A. catenella by using LM was also investigated as both species are present in Osaka Bay and have a similar size (John et al., 2014), whereas other morphological features, e.g. presence/absence of a ventral pore are not observable without staining and epifluoresence. However, based on the MPS-data, OTU associated with A. pacificum was only detected on one occasion from station 12 and thus misidentification does not seem plausible. Thus, the potential reasons causing the lack of correlation when using the full dataset from station 12 remains currently unresolved. Nevertheless, based on plotting the relative sequence abundances of OTU related with $A$. catenella and cell abundances obtained by LM, the patterns detected by both methods display similar patterns, demonstrating the effectivness of MPS to follow the bloom dynamics.

\section{Conclusions}

During four years of MPS-based monitoring, blooms of Alexandrium catenella occurred, when the water column was stable and the overall species diversity was reduced possibly due to low nutrient concentrations. Those factors can be used as the indices for $A$. catenella bloom occurrence to provide an early warning for local fisheries. The abundance of the toxic dinoflagellate $A$. catenella by morphology-based observation via microscopic analysis vs. the relative abundance recorded from MPS displayed similar fluctuation patterns between the two approaches, although the MPS-based method is not quantitative in principle. The comparability of two methods to detect the patterns in A. catenella abundances was further supported by the strong and statistically significant positive correlation.

\section{Data accessibility}

DNA sequences are available in the DDBJ Sequence Read Archive: PRJDB4580.

\section{Acknowledgments}

We thank Dr. Kyoko Yarimizu, National Research Institute of Fisheries Science, Japan Fisheries Research and Education Agency, for critical reading of the manuscript and encouragement during this study. A. Kondo and R. Kubota are thanked for their help with the molecular work. This work was supported by a Grant-in-Aid (Marine Metagenomics for Monitoring the Coastal Microbiota) by the Ministry of Agriculture, Forestry, and Fisheries of Japan; a Grant-in-Aid for Scientific Research (Kiban-B) by the Japan Society for the Promotion of
Science (Grant number:25292130); and a Grant-in-Aid by the Japanese Society for the Promotion of Science Fellows (Grant number: 02523180 and PE18028). [CG]

\section{Appendix A. Supplementary data}

Supplementary material related to this article can be found, in the online version, at doi:https://doi.org/10.1016/j.hal.2019.101660.

\section{References}

Abo, K., Yamamoto, T., 2019. Oligotrophication and its measures in the Seto Inland Sea, Japan. Bull. Jap. Fish. Edu. Agen. 49, 21-26. (accessed 10.06.2019). http://www. fra.affrc.go.jp/bulletin/bull/bull49/49-0504.pdf.

Adl, S.M., Simpson, A.G.B., Farmer, M.A., Andersen, R.A., Anderson, O.R., Barta, J.R., Bowser, S.S., Brugerolle, G., Fensome, R.A., Frederiqo, S., James, T.Y., Karpov, S., Kugrens, P., Krug, J., Christopher, E.L., Lewis, L.A., Lodge, J., Lynn, D.H., Mann, D.G. Mccourt, R.M., Mendoza, L., Moestrup, Ø., Mozley-Standridge, S.E., Neard, T.A., Shearer, C.A., Smirnov, A.V., Spiegel, F.W., Taylor, M.F.J.R., 2005. The new higher level classification of eukaryotes with emphasis on the taxonomy of protists. J. Eukaryot. Microbiol. 52, 399-451. https://doi.org/10.1111/j.1550-7408.2005. 00053.x.

Aguilera, A., Gómez, F., Lospitao, E., Amils, R., 2006. A molecular approach to the characterization of the eukaryotic communities of an extreme acidic environment: methods for DNA extraction and denaturing gradient gel electrophoresis analysis. Syst. Appl. Microbiol. 29, 593-605. https://doi.org/10.1016/J.SYAPM.2006.01.006.

Anderson, D.M., 2009. Approaches to monitoring, control and management of HABs. Ocean Coast. Manag. 52 (7), 342. https://doi.org/10.1016/j.ocecoaman.2009.04. 006.

Anderson, D.M., Keafer, B.A., McGillicuddy, D.J., Mickelson, M.J., Keay, K.E., Libby, P.S., Manning, J.P., Mayo, C.A., Whittaker, D.K., Hickey, J.M., He, R., Lynch, D.R., Smith, K.W., 2005. Initial observations of the 2005 Alexandrium fundyense bloom in southern New England: General patterns and mechanisms. Deep. Sea Res. Part Ii Top. Stud. Oceanogr. 52 (19-21), 2856-2876. https://doi.org/10.1016/j.dsr2.2005.09.004.

Anderson, M.J., Ellingsen, K.E., McArdle, B.H., 2006. Multivariate dispersion as a measure of beta diversity. Ecol. Lett. 9, 683-693. https://doi.org/10.1111/j.1461-0248. 2006.00926.x.

Anderson, D.M., Alpermann, T.J., Cembella, A.D., Collos, Y., Masseret, E., Montresor, M., 2012. The globally distributed genus Alexandrium: multifaceted roles in marine ecosystems and impacts on human health. Harmful Algae 14, 10-35. https://doi.org/ 10.1016/j.hal.2011.10.012.

Anjusha, A., Jyothibabu, R., Jagadeesan, L., Mohan, A.P., Sudheesh, K., Krishna, K., Ullas, N., Deepak, M.P., 2013. Trophic efficiency of plankton food webs: observations from the Gulf of Mannar and the Palk Bay, Southeast Coast of India. J. Mar. Syst. 115-116, 40-61. https://doi.org/10.1016/J.JMARSYS.2013.02.003.

Archibald, J.M., 2009. The puzzle of plastid evolution. Curr. Biol. 19, R81-R88. https:// doi.org/10.1016/J.CUB.2008.11.067.

Asano, Y., Oikawa, H., Yasuike, M., Fujiwara, A., Yamamoto, K., Nagai, S., Kobayashi, T, Gojobori, T., 2019. Mining of knowledge relating to factors in- volved in the aberrant growth of plankton. In: Gojobori, T., Wada, T., Kobayashi, T., Mineta, K. (Eds.), Marine Metagenomics: Technological Aspects and Applications. Springer [in press].

Azam, F., Fenchel, T., Field, J.G., Gray, J.S., Meyer-Reil, L.A., Thingstad, F., 1983. The ecological role of water-column microbes in the sea. Mar. Ecol. Progr. Ser. 10, 257-263. https://doi.org/10.3354/meps010257.

Balech, E., 1995. . The Genus Alexandrium halim (Dinoflagellate). Sherkin Island Marine Station, Sherkin Island, County Cork, Ireland.

Beaugrand, G., Edwards, M., Legendre, L., 2010. Marine biodiversity, ecosystem functioning, and carbon cycles. PNAS 107 (22), 10120-10124. https://doi.org/10.1073/ pnas.0913855107.

Berdalet, E., Fleming, L.E., Gowen, R., Davidson, K., Hess, P., Backer, L.C., Moore, S.K., Hoagland, P., Enevoldsen, H., 2016. Marine harmful algal blooms, human health and wellbeing: challenges and opportunities in the 21st century. J. Mar. Biol. Assoc. U.K. 96, Spec. Iss. 1, 61-91. https://doi.org/10.1017/S0025315415001733. 
Burki, F., Shalchian-Tabrizi, K., Minge, M., Skjæveland, Å., Nikolaev, S.I., Jakobsen, K.S., Pawlowski, J., 2007. Phylogenomics reshuffles the eukaryotic supergroups. PLoS One 2, e790.

Camacho, C., Coulouris, G., Avagyan, V., Ma, N., Papadopoulos, J., Bealer, K., Madden, T.L., 2009. BLAST + : architecture and applications. BMC Bioinformatics 10, 421. https://doi.org/10.1186/1471-2105-10-421.

Camarena-Gómez, M.T., Lipsewers, T., Piiparinen, J., Eronen-Rasimus, E., PerezQuemaliños, D., Hoikkala, L., Sobrino, C., Spilling, K., 2018. Shifts in phytoplankton community structure modify bacterial production, abundance and community composition. Aquat. Microb. Ecol. 81, 149-170. https://doi.org/10.3354/ame01868.

Caron, D.A., Countway, P.D., Jones, A.C., Kim, D.Y., Schnetzer, A., 2012. Marine protistan diversity. Ann. Rev. Mar. Sci. 4, 467-493. https://doi.org/10.1146/annurev-marine120709-142802.

Cheung, M.K., Au, C.H., Chu, K.H., Kwan, H.S., Wong, C.K., 2010. Composition and genetic diversity of picoeukaryotes in subtropical coastal waters as revealed by 454 pyrosequencing. ISME J. 4, 1053.

Cordier, T., Lanzén, A., Apothéloz-Perret-Gentil, L., Stoeck, T., Pawlowski, J., 2018. Embracing environmental genomics and machine learning for routine biomonitoring. Trends Microbiol. 27 (5), 387-397. https://doi.org/10.1016/j.tim.2018.10.012.

de Vargas, C., Audic, S., Henry, N., Decelle, J., Mahé, F., Logares, R., Lara, E., Berney, C., Le Bescot, N., Probert, I., Carmichael, M., Poulain, J., Romac, S., Colin, S., Aury, J.M., Bittner, L., Chaffron, S., Dunthorn, M., Engelen, S., Flegontova, O., Guidi, L., Horák, A., Jaillon, O., Lima-Mendez, G., Lukeš, J., Malviya, S., Morard, R., Mulot, M., Scalco, E., Siano, R., Vincent, F., Zingone, A., Dimier, C., Picheral, M., Searson, S., Kandels-Lewis, S., Acinas, S.G., Bork, P., Bowler, C., Gorsky, G., Grimsley, N., Hingamp, P., Iudicone, D., Not, F., Ogata, H., Pesant, S., Raes, J., Sieracki, M.E., Speich, S., Stemmann, L., Sunagawa, S., Weissenbach, J., Wincker, P., Karsenti, E. 2015. Eukaryotic plankton diversity in the sunlit ocean. Science 348 (6237), 1261605. https://doi.org/10.1126/science.1261605.

Duffy, J.E., Stachowicz, J.J., 2006. Why biodiversity is important to oceanography: potential roles of genetic, species, and trophic diversity in pelagic ecosystem processes. Mar. Ecol. Prog. Ser. 311, 179-189. https://doi.org/10.3354/meps311179.

Dyson, K., Huppert, D.D., 2010. Regional economic impacts of razor clam beach closures due to harmful algal blooms (HABs) on the Pacific coast of Washington. Harmful Algae 9 (3), 264-271. https://doi.org/10.1016/j.hal.2009.11.003.

Dzhembekova, N., Urusizaki, S., Moncheva, S., Ivanova, P., Nagai, S., 2017. Applicability of massively parallel sequencing on monitoring harmful algae at Varna Bay in the Black Sea. Harmful Algae 68, 40-51. https://doi.org/10.1016/j.hal.2017.07.004.

Edler, L., Elbrächter, M., 2010. The utermöhl method for quantitative phytoplankton analysis. In: Karlson, B., Cusack, C., Bresnan, E. (Eds.), Microscopic and Molecular Methods for Quantitative Phytoplankton Analysis. IOC Manuals and Guides, No. 55 UNESCO, Paris, pp. 5-12. (accessed: 05.06.2019). https://cdn.ioos.noaa.gov/media/ 2017/12/WKNCT_Handbook_ver5May2010_2.pdf.

Elferink, S., Neuhaus, S., Wohlrab, S., Toebe, K., Voß, D., Gottschling, M., Lundholm, N., Krock, B., Koch, B.P., Zielinski, O., Cembella, A., John, U., 2017. Deep - sea Research I Molecular diversity patterns among various phytoplankton size-fractions in West Greenland in late summer. Deep-Sea Res. Part I 12, 54-69. https://doi.org/10.1016/ j.dsr.2016.11.002.

Fauchot, J., Levasseur, M., Roy, S., Gagon, R., Weise, A.M., 2005. Environmental factors controlling Alexandrium tamarense (Dinophyceae) growth rate during a red tide event in the St. Lawrence estuary (Canada). J. Phycol. 41 (2), 263-272. https://doi.org/10. 1111/j.1529-8817.2005.03092.x.

Fauchot, J., Saucier, F.J., Levasseur, M., Roy, S., Zakardjian, B., 2008. Wind-driven river plume dynamics and toxic Alexandrium tamarense blooms in the St. Lawrence estuary (Canada): a modeling study. Harmful Algae 7, 214-227. https://doi.org/10.1016/J. HAL. 2007.08.002.

Fraga, S., Sampedro, N., Larsen, J., Moestrup, Ø., Calado, A.J., 2015. Arguments against the proposal 2302 by John \& al. To reject the name Gonyaulax catenella (Alexandrium catenella). Taxon 64 (3), 634-635. https://doi.org/10.12705/643.15.

Frommolt, R., Werner, S., Paulsen, H., Goss, R., Wilhelm, C., Zauner, S., Maier, U.G. Grossman, A.R., Bhattacharya, D., Lohr, M., 2008. Ancient recruitment by chromists of green algal genes encoding enzymes for carotenoid biosynthesis. Mol. Biol. Evol. $25,2653-2667$.

Fukuyo, Y., 1985. Morphology of Protogonyaulax tamarensis (Lebour) Taylor and Protogonyaulax catenella (Whedon and Kofoid) Taylor from Japanese coastal waters. Bull. Mar. Sci. 37, 529-537.

Galluzzi, L., Bertozzini, E., Penna, A., Perini, F., Pigalarga, A., Graneli, E., Magnani, M., 2008. Detection and quantification of Prymnesium parvum (Haptophyceae) by realtime PCR. L. Appl. Microbio. 46, 261-266. https://doi.org/10.1111/j.1472-765X. 2007.02294.x.

Gamfeldt, L., Hillebrand, H., Jonsson, P.R., 2005. Species richness changes across two trophic levels simultaneously affect prey and consumer biomass. Ecol. Let. 8 (7), 696-703. https://doi.org/10.1111/j.1461-0248.2005.00765.x.

Garneau, M.-E., Schnetzer, A., Countway, P.D., Jones, A.C., Seubert, E.L., Caron, D.A., 2011. Examination of the seasonal dynamics of the toxic dinoflagellate Alexandrium catenella at Redondo Beach, California, by quantitative PCR. Appl. Env. Microbiol. 77 (21), 7669-7680. https://doi.org/10.1128/AEM.06174-11.

Gran-Stadniczeñko, S., Supraha, L., Egge, E.D., Edvardsen, B., 2017. Haptophyte Diversity and Vertical Distribution Explored by 18S and 28S Ribosomal RNA Gene Metabarcoding and Scanning Electron Microscopy. J. Eukaryot. Microbiol. 64 514-532. https://doi.org/10.1111/jeu.12388.

Gran-Stadniczeñko, S., Egge, E., Hostyeva, V., Logares, R., Eikrem, W., Edvardsen, B., 2018. Protist diversity and seasonal dynamics in skagerrak plankton communities as revealed by Metabarcoding and microscopy. J. Eukaryot. Microbiol. 0, 1-20. https:// doi.org/10.1111/jeu.12700.

Guillard, R.R.L., Kilham, P., 1977. The ecology of Marine planktonic diatoms. In: Werner,
D. (Ed.), The Biology of Diatoms. University of California Press, Berkeley, pp. 372-469.

Guiry, M.D., Guiry, G.M., 2019. AlgaeBase. World-wide Electronic Publication, National University of Ireland, Galway (taxonomic Information Republished from AlgaeBase with Permission of M.D. Guiry). Alexandrium Halim, 1960 (accessed: 10.06.2019). http://www.algaebase.org.

Hamano, Y., Kawatsu, K., Tsukamoto, T., 2002. Occurence of paralytic shellfish toxins in bivalves collected in Osaka Bay. Bull. Osaka Prefect. Insitute Public Heal. 40, 11-18 (In Japanese).

Hampl, V., Hug, L., Leigh, J.W., Dacks, J.B., Lang, B.F., Simpson, A.G.B., Roger, A.J., 2009. Phylogenomic analyses support the monophyly of Excavata and resolve relationships among eukaryotic "supergroups.". Proc. Natl. Acad. Sci. 106, 3859 LP3864.

Hirai, J., Katakura, S., Kasai, H., Nagai, S., 2017. Cryptic zooplankton diversity revealed by a metagenetic approach to monitoring metazoan communities in the coastal waters of the Okhotsk Sea, northeastern hokkaido. Front. Mar. Sci. 4, 1-13. https://doi. org/10.3389/fmars.2017.00379.

Hu, Y.O.O., Karlson, B., Charvet, S., Andersson, A.F., 2016. Diversity of pico- to Mesoplankton along the $2000 \mathrm{~km}$ salinity gradient of the Baltic Sea. Front. Microbio. 7, 679. https://doi.org/10.3389/fmicb.2016.00679.

Itakura, S., Yamaguchi, M., 2001. Germination characteristics of naturally occurring cysts of Alexandrium tamarense (Dinophyceae) in Hiroshima Bay, Inland Sea of Japan. Phycologia 40 (3), 263-267. https://doi.org/10.2216/i0031-8884-40-3-263.1.

Itakura, S., Yamaguchi, M., Yoshida, M., Fukuyo, Y., 2002. The seasonal occurrence of Alexandrium tamarense (Dinophyceae) vegetative cells in Hiroshima Bay, Japan. Fish. Sci. 68, 77-86.

Jobard, M., Rasconi, S., Sime-Ngando, T., 2010. Diversity and functions of microscopic fungi: a missing component in pelagic food webs. Aquat. Sci. 72, 255-268. https:// doi.org/10.1007/s00027-010-0133-z.

John, U., Medlin, L.K., Groben, R., 2005. Development of specific rRNA probes to distinguish between geographic clades of the Alexandrium tamarense species complex. J. Plankton Res. 27, 199-204. https://doi.org/10.1093/plankt/fbh160.

John, U., Litaker, R.W., Montresor, M., Murray, S., Brosnahan, M.L., Anderson, D.M., 2014. Formal revision of the Alexandrium tamarense species complex (Dinophyceae) taxonomy: the introduction of five species with emphasis on molecular-based (rDNA) classification. Protist 165, 779-804. https://doi.org/10.1016/j.protis.2014.10.001.

Johnson, C.L., Runge, J.A., Curtis, A.K., Durbin, E.G., Hare, J.A., Incze, L.S., Link, J.S. Melvin, G.D., O'Brien, T.D., Van Guelpen, L., 2011. Biodiversity and ecosystem function in the Gulf of Maine: pattern and role of zooplankton and pelagic nekton. PLoS One 6 (1), e16491. https://doi.org/10.1371/journal.pone.0016491.

Kotani, Y., Koyama, A., Yamaguchi, M., Imai, I., 1998. Distribution of resting cysts of the toxic dinoflagellate Alexandrium catanella and/ or A. Tamarense in the coastal areas of western Shikoku and Kyushu, Japan. Bull. Japan Soc. Fish Oceanogr. 62.

Laanaia, N., Vaquer, A., Fiandrino, A., Genovesi, B., Pastoureaud, A., Cecchi, P., Collos, Y., 2013. Wind and temperature controls on Alexandrium blooms (2000-2007) in Thau lagoon (Western Mediterranean). Harmful Algae 28, 31-36. https://doi.org/10. 1016/j.hal.2013.05.016.

Lelong, A., Hégaret, H., Soudant, P., Bates, S.S., 2012. Pseudo-nitzschia (Bacillariophyceae) species, domoic acid and amnesic shellfish poisoning: revisiting previous paradigms. Phycologia 51, 168-216. https://doi.org/10.2216/11-37.

MacIntyre, J.G., Cullen, J.J., Cembella, A.D., 1997. Vertical migration, nutrition and toxicity in the dineflagellate Alexandrium tamarense Mar. Ecol. Progr. Ser. 148, 201-216. https://doi.org/10.3354/meps148201.

MacKenzie, L., Todd, K., 2002. Alexandrium camurascutulum sp. Nov. (Dinophyceae): a new dinoflagellate species from New Zealand. Harmful Algae 1, 295-300. https:// doi.org/10.1016/S1568-9883(02)00045-8.

Margalef, R., Estrada, M., Blasco, D., 1979. Functional morphology of organisms involved in red tides, as adpted to decaying turbulence. In: Taylor, D., Seliger, H. (Eds.), Toxic Dinoflagellate Blooms. Elsevier, New York, pp. 89-94.

McMurdie, P., Holmes, S., 2014. Waste not, want not : why rarefying microbiome data is inadmissible. PLoS Comput. Biol. 10 (4), e100353. https://doi.org/10.1371/journal. pcbi.1003531.

Medlin, L.J., Orozco, J., 2017. Molecular techniques for the detection of organisms in aquatic environments, with emphasis on harmful algal bloom species. Sensors 17 , 1184. https://doi.org/10.3390/s17051184.

Moestrup, Ø., Akselmann-Cardella, R., Fraga, S., Hoppenrath, M., Iwataki, M., Komárek, J., Larsen, J., Lundholm, N., Zingone, A. (Eds.), 2019. Taxonomic Reference List of Harmful Micro Algae. IOC-UNESCO (accessed: 05.06.2019) doi:10.14284/362. http://www.marinespecies.org/hab.

Montressor, M., John, U., Beran, A., Medlin, L.K., 2004. Alexandrium tamutum sp. Nov. (Dinophyceae): a new nontoxic species in the genus Alexandrium. J. Phycol. 40, 398-411. https://doi.org/10.1111/j.1529-8817.2004.03060.x.

Nagai, S., 2018. Marine eukaryote and HAB monitoring in Japan with next generation technology. Harmful Algae News 60, 1-3.

Nagai, S., Hori, Y., Miyahara, K., Manabe, T., Imai, I., 1996. Population dynamics of coscinodiscus wailesii Gran (bacillariophyceae) in harima-nada, Seto inland Sea, Japan. In: Yasumoto, T., Oshima, Y., Fukuyo, Y. (Eds.), Harmful and Toxic Algal Blooms. IOC of UNESCO, Paris, pp. 239-242.

Nagai, S., Matsuyama, Y., Oh, S.-J., Itakura, S., 2004. Effect of nutrients and temperature on encystment of the toxic dinoflagellate Alexandrium tamarense (Dinophyceae) isolated from Hiroshima Bay, Japan. Plankt. Biol. Ecol. 51, 667-675.

Nagai, S., Yamamoto, K., Hata, N., Itakura, S., 2012. Study of DNA extraction methods for use in loop-mediated isothermal amplification detection of single resting cysts in the toxic dinoflagellates Alexandrium tamarense and A. Catenella. Mar. Genom. 7, 51-56. https://doi.org/10.1016/J.MARGEN.2012.03.002.

Nagai, S., Hida, K., Urusizaki, S., Takano, Y., Hongo, Y., Kameda, T., Abe, K., 2016a. 
Massively parallel sequencing-based survey of eukaryotic community structures in Hiroshima Bay and Ishigaki Island. Gene 576, 681-689. https://doi.org/10.1016/J GENE.2015.10.026.

Nagai, S., Hida, K., Urushizaki, S., Onitsuka, G., Yasuike, M., Nakamura, Y., Fujiwara, A., Tajimi, S., Kimoto, K., Kobayashi, T., Ototake, M., 2016b. Influences of diurnal sampling bias on fixed-point monitoring of plankton biodiversity determined using a massively parallel sequencing-based technique. Gene 576, 667-675. https://doi.org/ 10.1016/J.GENE.2015.10.025.

Nagai, S., Miyamoto, S., Ino, K., Tajimi, S., Nishi, H., Tomono, J., 2016c. Easy detection of multiple Alexandrium species using DNA chromatography chip. Harmful Algae 51, 97-106. https://doi.org/10.1016/J.HAL.2015.10.014.

Nagai, S., Urusizaki, S., Hongo, Y., Chen, H., Dzhembekova, N., 2017. An attempt to semiquantify potentially toxic diatoms of the genus Pseudo-nitzschia in Tokyo Bay, Japan by using massively parallel sequencing technology. Plankt. Benthos Res. 12, 248-258. https://doi.org/10.3800/pbr.12.248.

Natsuike, M., Yamamoto, K., Nakajima, M., Sawayama, S., Imai, I., 2018. Comparison of nutrient availabilities between the toxic dinoflagellate Alexandrium tamarense and the non-toxic diatom Skeletonema sp. In Osaka Bay. Bull. Fish. Sci. Hokkaido Univ. 68 (1), 17-26. https://doi.org/10.14943/bull.fish.68.1.17. (In Japanese with English abstract)

Nishikawa, T., Hori, Y., Nagai, S., Miyahara, K., Nakamura, Y., Harada, K., Tanda, M., Manabe, T., Tada, K., 2010. Nutrient and phytoplankton dynamics in Harima-Nada, Eastern Seto Inland Sea, Japan during a 35-Year period from 1973 to 2007. Estuaries Coasts 33, 417-427. https://doi.org/10.1007/s12237-009-9198-0.

Nübel, U., Garcia-Pichel, F., Kühl, M., Muyzer, G., 1999. Quantifying microbial diversity: morphotypes, 16S rRNA genes, and carotenoids of oxygenic phototrophs in microbial mats. Appl. Environ. Microbiol. 65, 422-430 https://doi.org/0099-2240/99/ $\$ 04.00$ ?. 0 .

Oh, S.J., Yamamoto, T., Katoka, Y., Matsuda, O., Matsuyama, Y., Kotani, Y., 2002 Utilization of dissolved organic phosphorus by the two toxic dinoflagellates, Alexandrium tamarense and Gymnodinium catenatum (Dinophyceae). Fish. Sci. 68 416-424. https://doi.org/10.1046/j.1444-2906.2002.00440.x.

Okamoto, N., Chantangsi, C., Horák, A., Leander, B.S., Keeling, P.J., 2009. Molecular Phylogeny and Description of the Novel Katablepharid Roombia truncata gen. Et sp. nov., and Establishment of the Hacrobia taxon nov. PLoS One 4, e7080.

Oksanen, J., Blanchet, F.G., Friendly, M., Kindt, R., Legendre, P., McGlinn, D., Minchin, P.R., O'Hara, R.B., Simpson, G.L., Solymos, P., Stevens, M.H.H., Szoecs, E., Wagner, H., 2019. R Package Version 2.3-1. vegan: Community Ecology Package.

Penna, A., Casabianca, S., Perini, F., Bastianini, M., Riccardi, E., Pigozzi, S., Scardi, M., 2013. Toxic Pseudo-nitzschia spp. In the northwestern Adriatic Sea: characterization of species composition by genetic and molecular quantitative analyses. J. Plank. Res. 35 (2), 352-366.

Perneger, T.V., 1998. What's wrong with Bonferroni adjustments. BMJ 316 (7139), 1236-1238. https://doi.org/10.1136/bmj.316.7139.1236.

Piredda, R., Claverie, J.-M., Decelle, J., de Vargas, C., Dunthorn, M., Edvardsen, B., Eikrem, W., Forster, D., Kooistra, W.H.C.F., Logares, R., Massana, R., Montresor, M., Not, F., Ogata, H., Pawlowski, J., Romac, S., Sarno, D., Stoeck, T., Zingone, A., 2018. Diatom diversity through HTS-metabarcoding in coastal European seas. Sci. Rep. 8, 1038. https://doi.org/10.1038/s41598-018-36345-9.

Plum, C., Hüsener, M., Hillebrand, H., 2015. Multiple vs. Single phytoplankton species alter stoichiometry of trophic interaction with zooplankton. Ecol. 96 (11), 3075-3089. https://doi.org/10.1890/15-0393.1.

Ptacnik, R., Solimini, A.G., Andersen, T., Tamminen, T., Brettum, P., Lepistö, L., Willén, E., Rekolainen, S., 2008. Diversity predicts stability and resource use efficiency in natural phytoplankton communities. PNAS 105 (13), 5134-5138. https://doi.org/10. 1073/PNAS.0708328105.

R Core Team, 2019. R: A Language and Environment for Statistical Computing. R Foundation for Statistical Computing, Vienna, Austria.

Revelle, W., 2019. psych: Procedures for Personality and Psychological Research. Northwestern University, Evanston, Illinois, USA. https://CRAN.R-project.org/ package $=$ psychVersion $=1.8 .10$.

Ruvindy, R., Bolch, C.J., MacKenzie, L., Smith, K.F., Murray, S.A., 2018. qPCR assays for the detection and quantification of multiple paralytic shellfish toxin-producing species of Alexandrium. Front. Microbiol. 9, 3153.

Sakaguchi, M., Takishita, K., Matsumoto, T., Hashimoto, T., Inagaki, Y., 2009. Tracing back EFL gene evolution in the cryptomonads-haptophytes assemblage: separate origins of EFL genes in haptophytes, photosynthetic cryptomonads, and goniomonads. Gene 441, 126-131. https://doi.org/10.1016/J.GENE.2008.05.010.

Sekiguchi, K., Watanabe, S., Shimizu, M., Saito, S., 1986. Occurence of Protogonyaulax tamarensis on the coast of Iwate Prefecture, in relation to toxification of the scallop Patinopecten yessoensis. Bull. Tohoku Reg. Fish Res. Lab. 48, 115-123.

Sherr, E., Sherr, B., 1994. Bacterivory and herbivory: key roles of phagotrophic protists in pelagic food webs. Microb. Ecol. 28 (2), 223-235. https://doi.org/10.1007/ BF00166812.

Sherr, B., Sherr, E., Caron, D., Vaulot, D., Worden, A., 2011. Oceanic protists. Oceanogr. 20 (2), 130-134. https://doi.org/10.5670/oceanog.2007.57.

Shimada, H., Sawada, M., Fukamachi, Y., 2012. A method for predicting the occurrence of paralytic shellfish poisoning along the coast of Hokkaido in the Okhotsk Sea in summer. Fish. Sci. 78, 865-877. https://doi.org/10.1007/s12562-012-0513-5.

Sildever, S., Kawakami, Y., Kanno, N., Kasai, H., Shiomoto, A., Katakura, S., Nagai, S., 2019. Toxic HAB species from the Sea of Okhotsk detected by a metagenetic approach, seasonality and environmental drivers. Harmful Algae 87, 101631. https:// doi.org/10.1016/j.hal.2019.101631.

Simpson, E.H., 1949. Measurement of diversity. Nature 163, 688

Smayda, T.J., 1980. Species Succession. University of California Press, Berkeley.

Smayda, T.J., 1998. Patterns of variability characterizing marine phytoplankton, with examples from Narragansett Bay. ICES J. Mar. Sci. 55, 562-573.

Smayda, T.J., Reynolds, C.S., 2003. Strategies of marine dinoflagellate survival and some rules of assembly. J. Sea Res. 49, 95-106. https://doi.org/10.1016/S1385-1101(02) 00219-8.

Sogin, M.L., Morrison, H.G., Huber, J.A., Welch, D.M., Huse, S.M., Neal, P.R., Arrieta, J.M., Herndl, G.J., 2006. Microbial diversity in the deep sea and the underexplored"rare biosphere". Proc. Natl. Acad. Sci. U. S. A. 103, 12115-12120. https:// doi.org/10.1073/pnas.0605127103.

Spilling, K., Olli, K., Lehtoranta, J., Kremp, A., Tedesco, L., Tamelander, T., Klais, R., Peltonen, H., Tamminen, T., 2018. Shifting diatom-dinoflagellate dominance during spring bloom in the Baltic Sea and its potential effects on biogeochemical cycling. Front. Mar. Sci. 5, 327. https://doi.org/10.3389/fmars.2018.00327.

Stomp, M., van Dijk, M.A., van Overzee, H.M.J., Wortel, M.T., Sigon, C.A.M., Egas, M., Hoogveld, H., Gons, H.J., Huisman, J., 2008. The timescale of phenotypic plasticity and its impact on competition in fluctuating environments. Am. Nat. 172, E169-E185. https://doi.org/10.1086/591680.

Sze, Y., Miranda, L.N., Sin, T.M., Huang, D., 2018. Characterising planktonic dinoflagellate diversity in Singapore using DNA metabarcoding. Metabar. Metagen. 2, 1-14. https://doi.org/10.3897/mbmg.2.25136.

Tanabe, A.S., 2012a. Claident v0120130723. software distributed by the author at http://wwwclaidentorg/.

Tanabe, A.S., 2012a. Claident v0120130723, software distributed by the author at http:// wwwclaidentorg/.

Tanabe, A.S., Nagai, S., Kohsuke, H., Motoshige, Y., Atushi, F., Yoji, N., Yoshihito, T., Seiji, K., 2016. Comparative study of the validity of three regions of the 18S-rRNA gene for massively parallel sequencing-based monitoring of the planktonic eukaryote community. Mol. Ecol. Resour. 16, 402-414. https://doi.org/10.1111/1755-0998. 12459.

Taylor, F.J.R., Waters, R.E., 1982. Spring phytoplankton in the Subarctic North Pacific Ocean. Mar. Biol. 67, 323-335. https://doi.org/10.1007/BF00397673.

Therriault, J.C., Painchaud, K., Levasseur, M., 1985. Factors controlling the occurence of protogonyaulax tamarensis and shellfish toxicity in the St. Lawrence estuary: freshwater runoff and stability of the water column. In: Anderson, D.M., White, A.W., Baden, D.G. (Eds.), Toxic Dinoflagellates. Elsevier, New York, pp. 141-146.

Tomas, C.R., 1997. Identifying Marine Phytoplankton. Academic Press, San Diego. https://doi.org/10.1016/B978-012693018-4/50000-8.

Uchida, T., Kawamata, K., Nishihama, Y., 1980. Vertical distribution of paralytic toxinproducing species, Protogonyaulax sp. In Funka Bay, Hokkaido, Japan. J. Phycol. 25, 133-139.

Uchida, T., Toda, S., Nakamura, O., Abo, K., Matsuyama, Y., Honjyo, T., 1998. Initial site of Gymnodinium mikitomoi blooms in relation to the seawater exchange rate in Gokasyo Bay, Japan. Plankt. Biol. Ecol. 45, 129-137.

Weise, A.M., Levasseur, M., Saucier, F.J., Senneville, S., Bonneau, E., Roy, S., Sauvé, G., Michaud, S., Fauchot, J., 2002. The link between precipitation, river runoff, and blooms of the toxic dinoflagellate Alexandrium tamarense in the St. Lawrence. Can. J. Fish. Aquat. Sci. 59, 464-473. https://doi.org/10.1139/f02-024.

Weiss, S., Xu, Z.Z., Peddada, S., Amir, A., Bittinger, K., Gonzales, A., Lozupone, C., Zaneveld, J.R., Vásquez-Baeza, Y., Birmingham, A., Hyde, E.R., Knight, R., 2017. Normalization and microbial differential abundance strategies depend upon data characteristics. Microbiome 5, 27. https://doi.org/10.1186/s40168-017-0237-y.

Wollschläger, J., Wiltshire, K.H., Petersen, W., Metfies, K., 2015. Analysis of phytoplankton distribution and community structure in the German Bight with respect to different size classes. J. Sea Res. 99, 83-96. https://doi.org/10.1016/j.seares.2015. 02.005 .

Xiao, X., Sogge, H., Lagesen, K., Tooming-Klunderud, A., Jakobsen, K.S., Rohrlack, T., 2014. Use of high throughput sequencing and light microscopy show contrasting results in a study of phytoplankton occurrence in a freshwater environment. PLOS One 9 (8), e106510. https://doi.org/10.1371/journal.pone.0106510.

Yamamoto, T., 2003. The Seto Inland Sea-eutrophic or oligotrophic? Mar. Pollut. Bull. 47, 37-42. https://doi.org/10.1016/S0025-326X(02)00416-2.

Yamamoto, K., 2004. Occurence of Paralytic Shellfish Toxins in the spring of 2002 in east side of Osaka Bay. Bull. Osaka Prefect. Fish Exp. Stn. 15, 1-8 (In Japanese).

Yamamoto, K., Oikawa, H., 2017. Temporal changes and differences in the toxin contents and the profiles between arc shell and Japanese cockle contaminated with paralytic shellfish toxin in Osaka Bay. Nippon. Suisan Gakkaishi 83 (4), 589-598 (In Japanese with an English abstract).

Yamamoto, K., Yamasaki, M., 1996. Japanese monitoring system on shellfish toxins. In: Yasumoto, T., Oshima, Y., Fukuyo, Y. (Eds.), Harmful and Toxic Algal Blooms. Internation Ocenaographic Commission of UNESCO, Paris, pp. 19-22.

Yamamoto, T., Hashimoto, T., Tarutani, K., Kotani, Y., 2002. Effects of winds, tides and river water runoff on the formation and disappearance of the Alexandrium tamarense bloom in Hiroshima Bay, Japan. Harmful Algae 1, 301-312. https://doi.org/10. 1016/S1568-9883(02)00029-X.

Yamamoto, K., Nakajima, M., Tabuchi, K., Hamano, Y., 2009. A novel red tide of the toxic dinoflagellate Alexandrium tamarense and resultant contamination of paralytic shellfish toxins in bivalves in the spring of 2007 in Osaka Bay. Bullet. Plankt. Soc. Japan 56, 13-23 (In Japanese with an English abstract).

Yamamoto, K., Matsuyama, Y., Ohmi, H., Ariyama, H., 2010. Diel vertical migration of the toxic dinofragellate Alexandrium tamarense, temporal changes of associated environmental factors and cell toxin content during the course of a large-scale bloom. Nippon. Suisan Gakkaishi 76 (5), 877-885 (In Japanese with an English abstract).

Yamamoto, K., Ohmi, H., Sano, M., 2011. Occurence of a red tide of the toxic dinoflagellate Alexandrium tamarense in the estuary of the Yodo River in 2007 - dynamics of the vegetative cells and cysts. Bullet. Plankt. Soc. Japan 58, 136-145 (In Japanese with an English abstract).

Yamamoto, K., Tsujimura, H., Nakajima, M., Harrison, P.J., 2013. Flushing rate and 
salinity may control the blooms of the toxic dinoflagellate Alexandrium tamarense in a river/estuary in Osaka Bay, Japan. J. Oceanogr. 69, 727-736. https://doi.org/10. 1007/s10872-013-0203-7.

Yamamoto, K., Nakajima, M., Imai, I., 2017. Expansion of blooming in the toxic dinoflagellate Alexandrium tamarense and environmental fluctuation analyzed from longterm monitoring data in Osaka Bay, eastern Seto Inland Sea, Japan. Bull. Plankton Soc. Japan 64 (1), 11-21 (In Japanese with an English abstract).

Yu, L., Zhang, W., Liu, L., Yang, J., 2015. Determining microeukaryotic plankton community around Xiamen Island, Southeast China, using Illumina MiSeq and PCRDGGE techniques. PLoS One 10 (5), e0127721. https://doi.org/10.1371/journal. pone. 0127721 .

Zhu, F., Massana, R., Not, F., Marie, D., Vaulot, D., 2005. Mapping of picoeucaryotes in marine ecosystems with quantitative PCR of the 18S rRNA gene. FEMS Microbiol. Ecol. 52, 79-92. https://doi.org/10.1016/j.femsec.2004.10.006.

Zingone, A., Enevoldsen, H.O., 2000. The diversity of harmful algal blooms: a challenge for science and management. Ocean Coast. Manag. 43, 725-748. 